\title{
DEMOGRAPHIC CHANGE AND FISCAL SUSTAINABILITY IN ASIA
}

Sang-Hyop Lee, Jungsuk Kim, and Donghyun Park

NO. 481

April 2016
ADB ECONOMICS WORKING PAPER SERIES 
ADB Economics Working Paper Series

\section{Demographic Change and Fiscal Sustainability in Asia}

Sang-Hyop Lee, Jungsuk Kim, and Donghyun Park

No. 481 | April 2016
Sang-Hyop Lee (leesang@hawaii.edu) is a professor in the Department of Economics at the University of Hawaii at Manoa. Jungsuk Kim (iias7@sogang.ac.kr.) is a researcher in the Institute of International and Area Studies at Sogang University. Donghyun Park (dpark@adb.org) is a principal economist in the Economics and Research Department at the Asian Development Bank. 
Asian Development Bank

6 ADB Avenue, Mandaluyong City

1550 Metro Manila, Philippines

www.adb.org

(C) 2016 by Asian Development Bank

April 2016

ISSN 2313-6537 (Print), 2313-6545 (e-ISSN)

Publication Stock No. WPS167973-2

The views expressed in this paper are those of the authors and do not necessarily reflect the views and policies of the Asian Development Bank (ADB) or its Board of Governors or the governments they represent.

ADB does not guarantee the accuracy of the data included in this publication and accepts no responsibility for any consequence of their use.

By making any designation of or reference to a particular territory or geographic area, or by using the term "country" in this document, $A D B$ does not intend to make any judgments as to the legal or other status of any territory or area.

Note: In this publication, "\$” refers to US dollars.

The ADB Economics Working Paper Series is a forum for stimulating discussion and eliciting feedback on ongoing and recently completed research and policy studies undertaken by the Asian Development Bank (ADB) staff, consultants, or resource persons. The series deals with key economic and development problems, particularly those facing the Asia and Pacific region; as well as conceptual, analytical, or methodological issues relating to project/program economic analysis, and statistical data and measurement. The series aims to enhance the knowledge on Asia's development and policy challenges; strengthen analytical rigor and quality of ADB's country partnership strategies, and its subregional and country operations; and improve the quality and availability of statistical data and development indicators for monitoring development effectiveness.

The ADB Economics Working Paper Series is a quick-disseminating, informal publication whose titles could subsequently be revised for publication as articles in professional journals or chapters in books. The series is maintained by the Economic Research and Regional Cooperation Department. 


\section{CONTENTS}

TABLES AND FIGURES $\quad$ iv

ABSTRACT $v$

$\begin{array}{ll}\text { I. INTRODUCTION } & 1\end{array}$

II. METHODOLOGY 3

A. Projection Method 3

B. Issues 4

$\begin{array}{lll}\text { III. } & 6\end{array}$

A. Population and Gross Domestic Product Growth 6

B. Public Sector Finances $\quad 7$

IV. FISCALPROJECTIONS

A. $\quad$ Expenditure 11

B. Revenues and Fiscal Balance 16

V. DECOMPOSITION RESULTS

VI. CONCLUDING OBSERVATIONS

$\begin{array}{ll}\text { APPENDIX } & 25\end{array}$

$\begin{array}{lr}\text { REFERENCES } & 27\end{array}$ 


\section{TABLES AND FIGURES}

TABLES

$1 \quad$ Per Capita GDP Growth Rate Assumptions

2 Mapping of IMF Government Finance Statistics, Revenue to Tax Profiles 8

3 Model Profiles Based on Per Capita Income 9

$4 \quad$ Government Expenditure 12

5 Government Tax Revenue $\quad 13$

6 Government Revenue $\quad 14$

$7 \quad$ Fiscal Balance $\quad 15$

8 Tax Revenue, Decomposition of Change 20

9 Government Revenue, Decomposition of Change 21

10 Fiscal Balance, Decomposition of Change 22

A.1 Government Tax Revenue (holding 2010 fiscal balance constant) 25

A.2 Government Revenue (holding 2010 fiscal balance constant) 26

\section{FIGURES}

1 Per Capita Public Transfer Inflows and Outflows by Age $\quad 1$

2 Aggregate Public Transfer Inflows and Outflows by Age 2

3 Aggregate Net Public Transfer by Age, Japan 2004 versus 2050

4 Model Profiles of Public Transfer Inflow on Social Welfare 10

5 Model Profiles of Public Transfer Outflow by Age of Tax Payers 10

6 Average Government Expenditure, Revenue, and Tax Revenue 17

7 Average Fiscal Balance 


\begin{abstract}
Changes in the population age structure can have a significant effect on fiscal sustainability since they can affect both government revenues and expenditures. For example, population aging will increase expenditures on the elderly while reducing potential growth and hence revenues. In this paper, we project government revenue, expenditure, and fiscal balance in developing Asia up to 2050. Using a simple stylized model and the National Transfer Accounts data set, we simulate the effect of both demographic changes and economic growth. Rapidly aging economies like the Republic of Korea; Japan; and Taipei,China, are likely to suffer a tangible deterioration of fiscal sustainability under their current tax and expenditure system. On the other hand, rapid economic growth can improve fiscal health in poorer economies with relatively young populations and still-growing working-age populations. Overall, our simulation results indicate that Asia's population aging will adversely affect its fiscal sustainability, pointing to a need for Asian economies to further examine the impact of demographic shifts on their fiscal health.
\end{abstract}

Keywords: Asia, fiscal balance, fiscal projection, population aging, public spending, tax

JEL codes: H20, H50, H62, J11, J14 


\section{INTRODUCTION}

In this paper, we project government revenue, spending, and fiscal balance in developing Asia up to 2050. By using the National Transfer Accounts (NTA) data set, United Nations (UN) population projections, and other data sources for long-range projections for real gross domestic product (GDP), we estimate the fiscal burdens that countries are likely to face as a result of both economic growth and demographic changes. Changes in population age structure matter for public finances simply because the beneficiaries of public programs are primarily children and the elderly, while the working-age population typically bears most of the tax burden. The fiscal balance can worsen rapidly if age-related expenditures such as health care for the elderly increase while the tax base shrinks due to the decline in the share of working-age population.

Asia has experienced very dramatic changes in its age structure over the last few decades and these changes are certain to continue in the future. During the 1950s and 1960s, most Asian countries except Japan, where young countries, but since 1970, the share of young people declined rapidly while the share of prime working ages increased. The share of 60 and older also increased in many countries, most notably in Japan. Asia is now entering the third phase of the transition, where the old-age population increases dramatically. By 2030, 20 of 42 Asian countries will have reached this final phase of the demographic transition.

Changes in age structure have a strong effect on financing public transfers. The beneficiaries of public programs are primarily children and the elderly while most of the fiscal burden is borne by the working-age population. Figure 1 shows Japan's per capita public transfer flows by age. These numbers are normalized by dividing the annual flows by the annual per capita labor income of persons aged 3049 , the prime working ages in most countries.

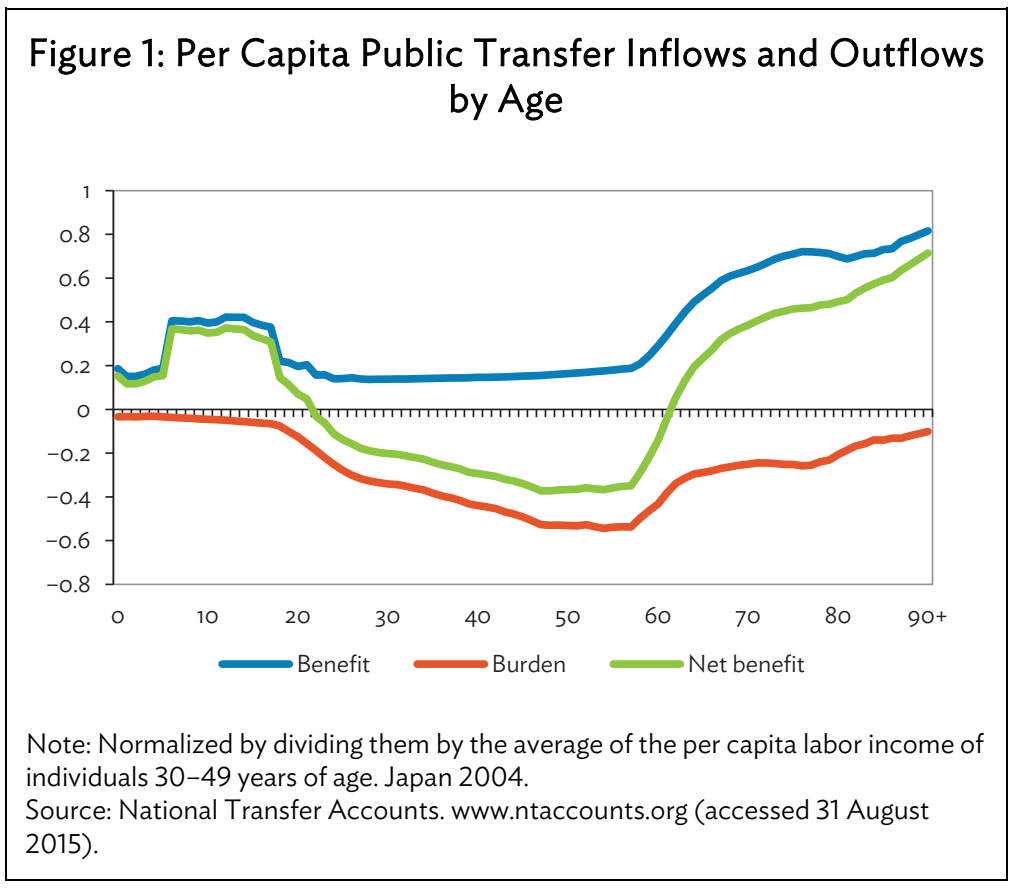


The benefit profiles for Japan shows two peaks. The first is for children, driven primarily by public spending on education, and the second peak is for the elderly, driven primarily by public pensions and publicly funded health care spending. The tax burden profiles peak around ages 45-55 when labor income peaks.

The aggregate flows by age are the product of the per capita flows shown in Figure 1 and population by age. These values are shown in Figure 2. The influence of Japan's old population age structure is clearly evident. Most public transfers go to the elderly.

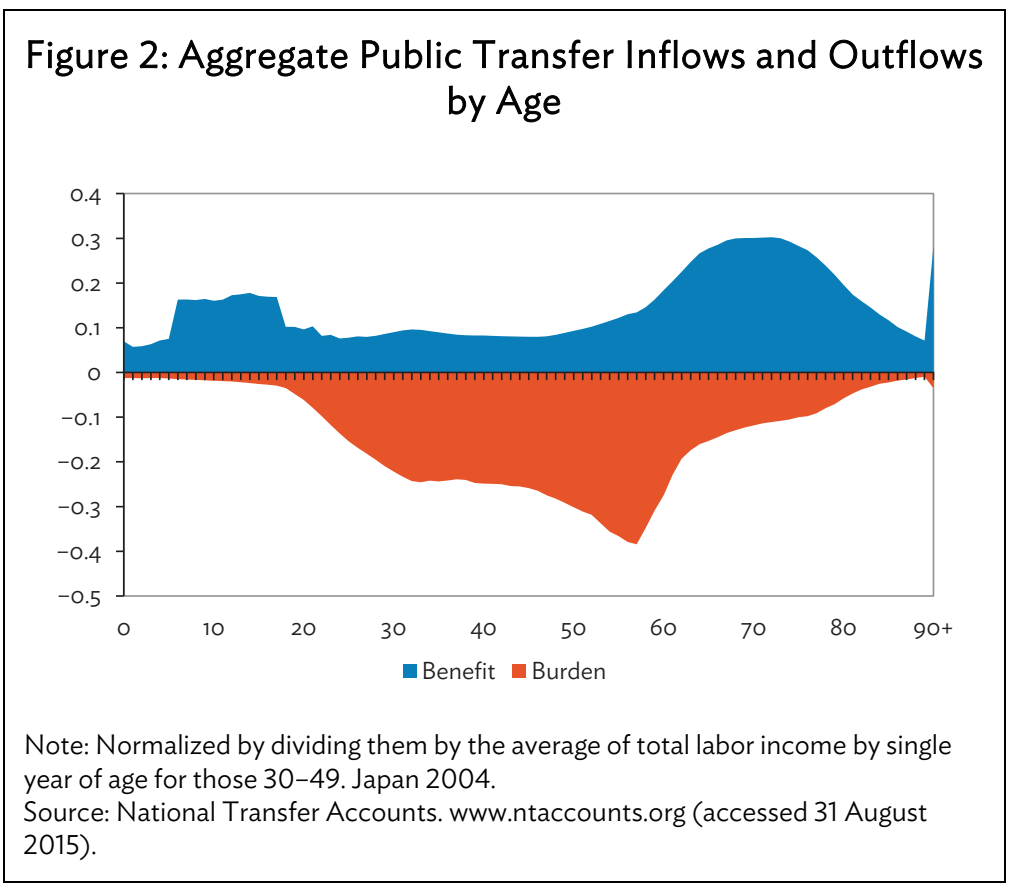

In Japan, population aging and current tax and benefit policies would lead to a fiscal deficit of $¥ 52$ trillion in 2050 in 2004 value (Figure 3 ). The projected $¥ 52$ trillion deficit comes mainly from the deficit of people aged 65 and older ( $¥ 33$ trillion), and a decrease in tax revenues from working people aged $20-64$ ( $¥ 24$ trillion). Due to very low fertility rate, about $¥ 6$ trillion of surplus is projected for people aged under 20 in 2050. Fifty-two trillion yen is about 58\% of government revenue in 2004 . Therefore, taxes must increase by $58 \%$, or benefits must decrease by the same amount, or deficits must increase, or some combination of these three cases must occur. This implies tax should increase 3.5\% per annum between 2004 and 2050 just to offset the effect of population aging if benefits and deficits remain constant at the 2004 level.

In contrast, many developing Asian countries will see a decrease in budget deficit or increase in surplus because their working-age populations will continue to expand. Rapid growth will also relax public sector budget constraints. The danger is that countries with favorable demographics and fast growth will implement generous transfer systems that ultimately prove to be unsustainable. In fact, lower-income countries in Asia spend relatively little on public programs for reasons that are largely unrelated to demographic conditions. As lower-income countries develop, however, the key issue for them is whether the public sector can expand at the same time that their populations are aging. 


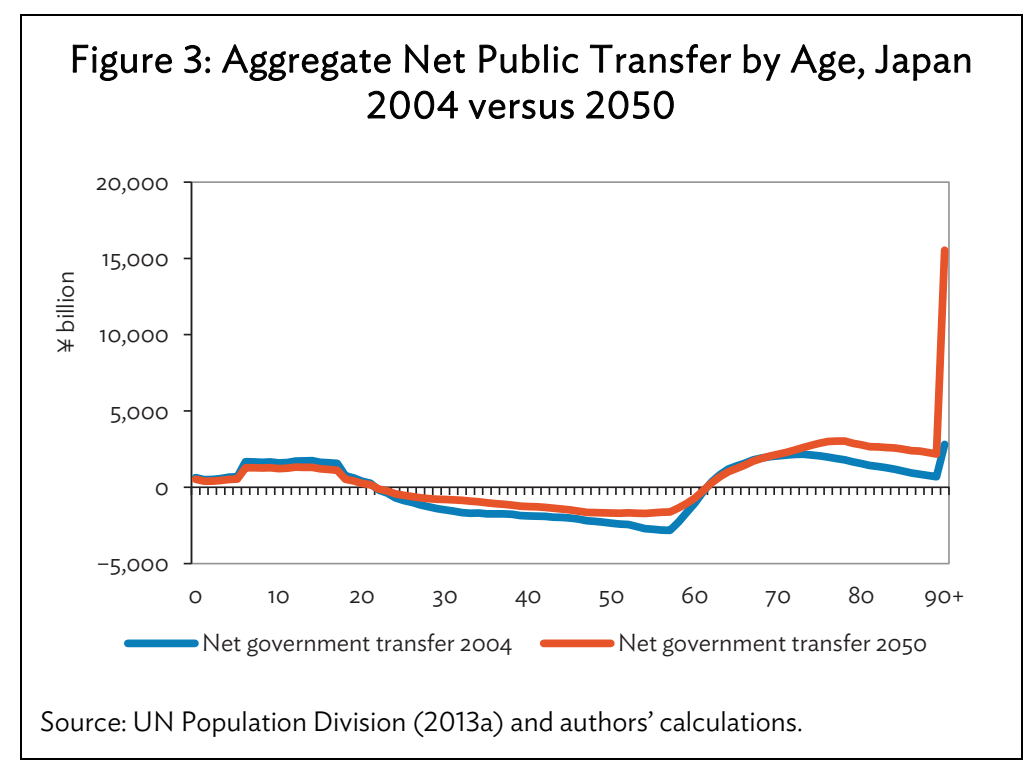

\section{METHODOLOGY}

The methodology is similar to Lee and Mason (2015), which was used to project public spending for education, health, and social protection spending. Following Lee and Mason (2015), we consider two main factors for our projections-changes in population age structure and changes in age-specific transfers due to projected changes in per capita income.

\section{A. Projection Method}

Let per capita transfers to persons age $x$ in year $t$ in country $z$ be designated by $b(z) t(x, t)$. For purposes of projection, we will use a normalized support ratio equal to public transfers per person relative to per capita income, $y(t)$, so that public transfers per person age $x$ in year $t$ in country $z$ is equal to $b(z) \tilde{\tau}(x, t) y(t)$ where $\tilde{\tau}(x, t)=\tau(x, t) / y(t)$. Thus, given the normalized transfer profile per capita, transfers are assumed to increase at the same rate as per capita income.

The normalized profile shifts upward in stepwise fashion as per capita income increases. In general, the normalized profile in year $t$ is given by:

$$
\tilde{\tau}(x, t)=\sum_{k=1}^{K} D_{k}[y(t)] \tilde{\tau}(x, k)
$$

where $D_{k}[y(t)]$ is a dummy variable that takes the value of 1 if per capita income in year $t$ falls in per capita income growth $k$ (otherwise the dummy variable is zero) and $\tilde{\tau}(x, k)$ is the model profile for income group $k$. Please refer to the text for the income groups and the model profiles for each group. Total transfers as a share of per capita gross national product (GNP) is thus computed as: 


$$
\begin{aligned}
\text { Transfers as a percentage of GNP } & =\frac{b(z) y(t) \sum \tilde{\tau}(x, t) N(x, t)}{y(t) N(t)} \\
& =b(z) \sum \tilde{\tau}(x, t) N(x, t) / N(t)
\end{aligned}
$$

The model is applied separately to revenue and spending using separate age profiles. We calculate the changes in tax burden and spending given the base year age profile of tax and benefits and the projected population age structure:

$$
\frac{\sum \tilde{\tau}\left(x, t_{0}\right) N(x, t) / N(t)}{\sum \tilde{\tau}\left(x, t_{0}\right) N\left(x, t_{0}\right) / N(x)}
$$

Equation (3) is the ratio of per capita tax (spending) in year $t$ relative to per capita tax (spending) on the program in the base year necessary to maintain the level of tax and benefits per person at each age.

Several features of this specification should be noted. First, it is important to understand that population size itself has no effect on tax revenue or public spending as a percentage of GDP although it affects the aggregate amount of revenue or spending. Since public expenditures which benefit everyone is assumed to increase at the same rate as per capita GDP, they do not affect our results. Nontax revenues are assumed to increase at the same rate as per capita GDP, so they do not affect our results either. It is instead the population age structure which has a direct effect on revenue or spending as a share of GDP. The underlying intuition is that tax burdens and benefits are concentrated at particular age groups, as discussed earlier. Second, growth in per capita income within income groups does not affect transfers as a percentage of GDP, all other things equal. We assume that countries increase tax and spending as per capita income rises. The larger relative size of the government in richer countries supports this assumption. Third, public transfers are scaled to match the initial level (year 2010 in this paper) of tax revenue, spending, and fiscal balance in each country. Countries with large public sectors are projected to have large public sectors in the future.

\section{B. Issues}

The rationales for using the two factors-(1) changes in population age structure and (2) changes in agespecific transfers due to projected changes in per capita income-are somewhat obvious. Countries are quite different in terms of their taxation and spending component. First, the age profiles of taxation depends a lot on the tax base (i.e., the source of tax is labor, asset income, corporate, or consumption) but the base differs a lot across countries. For example, while Japan and the Republic of Korea depend on income, corporate, and value-added taxes, which account for about $80 \%$ of their tax revenues, the Republic of Korea relies less on income taxes. The financing of social welfare expenditures is also different in the two countries.

Broadly speaking, the tax base consists of direct and indirect taxes. The choice between direct and indirect taxes has long been debated in both academic and political circles. Income taxes can be classified as direct taxes and the same is true for most taxes on assets and wealth. Indirect taxes such 
as value-added tax fall on transactions such as consumption. Martinez-Vazquez, Vulovic, and Liu (2009) show that in the last 3 decades, the average ratio of direct to indirect taxes has been rising, especially in developed countries. This is in large part due to the implementation of social security contributions. The importance of income taxes has declined in developing countries, while it has remained flat for developed countries. Within indirect taxes, there is an increase in consumption taxes, especially in developing countries.

There is a growing literature on the impact of the tax mix on economic growth, equity, and tax revenue. One part of this literature compares the effects of direct versus indirect tax choices in the context of the dynamic endogenous growth model. The evidence generally indicates that switching toward consumption taxation and away from income taxation has significant positive impact on growth and negative impact on income distribution (e.g., Li and Sarte 2004). Different taxes might also lead to different evasion outcomes. Since income taxes are easier to evade than indirect taxes, tax authorities are more likely to rely on indirect taxes where tax evasion prevails. Having said that, developing countries may rely more on indirect taxes, while developed countries tend to rely more on direct taxes. A number of empirical studies show that reliance on direct taxes rises with per capita income (Hines and Summers 2009; Estrada, Lee, and Park 2015). This has significant implications for tax burden by age, since the age profiles are quite different depending on the incidence of tax on income versus consumption.

Second, there is also a large variation across countries in terms of the expenditure mix. For example, about $40 \%$ of central government expenditure is nonage related in the median Organisation for Economic Co-operation and Development (OECD) country, compared to the nearly $70 \%$ in a county such as the Republic of Korea. This is because the Republic of Korea still devotes a relatively large share of government spending to public investment and economic infrastructure rather than social welfare-related spending. Hence, the Republic of Korea is less likely to be affected by population aging if we hold the profiles constant, compared with other OECD countries.

Third, there is an issue which is specifically related with Japan, which provides the target profiles of our model. Japan's tax revenues as a percent of GDP decreased from 14\% in 1990 to less than 10\% in 2012. As a result, Japan's tax burden decreased by 4.2 percentage points, while the average tax burden ratio in OECD changed little during the same period (around 25\%). In fact, the Japanese government cut their taxes in 1994, 1998, and 1999, while social welfare expenditure has been rising in large part due to population aging. Furthermore, the compensation of employees has grown little during the same period due to sluggish economy. Thus, the gap between the spending and the revenue has been expanding, resulting in accumulation of Japanese government debt. Simulation results in Kim (2015) show that Japan's fiscal position might have not deteriorated in the absence of tax cuts. The point here is that while Japan's welfare expenditure has increased, spending on economic infrastructure and others areas has gradually decreased. Japanese-style debt financing will not be possible for most Asian governments. In addition, the increase in tax revenue and expenditure will not be solely in the hands of the central government because the increase will be shared with local governments.

Our projections do not explain why some governments are bigger than others. In fact, there is no solid consensus on the determinants of government size, even though richer countries typically have larger governments. Public services require a certain critical minimum size, which implies that smaller economies tend to have bigger governments (Alesina and Wacziarg 1998). Openness may be linked to government size in a variety of ways because openness is a source of destabilizing external shocks (Rodrik 1996). Certain modes of political representation, in particular, proportional and parliamentarian democratic systems — can also induce bigger government (Persson and Tabellini 2004). 
We do not address differences across countries such as the tax base, composition of social expenditure, government size, or reliance on debt financing. In fact, there is little basis to make a longterm forecast of how tax revenue or public sector spending will change. Consequently, our projections based on recent revenue and spending trends in higher-income Asian countries serve as a guide to how revenue and spending are likely to change in lower-income Asian countries. In spite of these limitations, it is nevertheless useful to understand the deteriorating fiscal trends in countries like the Republic of Korea and Japan. For one, understanding Korean and Japanese trends can alert many Asian countries to the unsustainability of their current tax and expenditure systems.

Most of all, although the tax base and expenditure are key determinants of the age profile, it is clear that projections of government revenue, tax revenue, expenditure, and debt will also depend a lot on economic growth and population age structure. For example, the Republic of Korea's tax base will shrink and expenditure will increase markedly due to population aging and decline in potential growth rate. So it is plausible to assume that the impact of population aging will be substantial even allowing for diverse patterns of tax bases and expenditures across Asian countries. Due to older population and slower growth, the Republic of Korea's public debt to GDP ratio is projected to rise from 35\% in 2015 to over 200\% by 2060 (National Assembly Budget Office 2015).

\section{DATA}

In this section, we describe the data used in our analysis.

\section{A. Population and Gross Domestic Product Growth}

UN World Population Prospects, 2012 Revision (2013a), prepared by the UN Population Division of the Department of Economic and Social Affairs, is used for our analysis. All projections are based on the medium-fertility scenario. This scenario assumes that fertility will continue to decline in high-fertility countries and will recover toward replacement in low-fertility countries. Details are available on the UN Population Division website (http://www.un.org/en/development/desa/population/).

Long-term projections of real GDP are inherently difficult to construct. We rely on three sources of data, OECD projections for Japan, India, Indonesia, the Republic of Korea, the People's Republic of China (PRC), and Non-OECD countries up to 2060, Asian Development Bank (ADB) projections for ADB member economies up to 2030, and the International Macroeconomic Data Set from the US Department of Agriculture (USDA) for 190 countries up to 2030. Since ADB and USDA provide projections only up to 2030, OECD member and nonmember projections are used as a benchmark for extended projections up to 2050. ' Economies have been classified into four groups based on these three data sets. The projection results are influenced by the GDP growth assumptions only when countries graduate to a new income group. Many low-income countries do not exceed $\$ 5,000$ per capita income throughout the entire projection period, and many others reach a higher income level only near the end of the projection period.

\footnotetext{
1) OECD projections for Japan, India, Indonesia, the Republic of Korea, the PRC, and Non-OECD countries up to 2060 , (http://www.oecd.org/eco/outlook/lookingto2060.htm); 2) ADB projections for ADB member economies up to 2030 (http://www.iadb.org/intal/intalcdi/PE/2011/09482.pdf); and 3) The International Macroeconomic Data Set from the US Department of Agriculture for 190 countries up to 2030 (http://www.ers.usda.gov/data-products/internationalmacroeconomic-data-set/). As ADB and USDA provides projections only up to 2030, OECD member and nonmember projections are used as a benchmark for extended projections up to 2050.
} 
Table 1: Per Capita GDP Growth Rate Assumptions

\begin{tabular}{l|c|c}
\hline \multicolumn{1}{c|}{ Group and Economies } & \multicolumn{2}{c}{ Annual Rate of Real per Capita GDP Growth (\%) } \\
\cline { 2 - 3 } & $2010-2030$ & $2030-2050$ \\
\hline A: Mongolia, People's Republic of China, Bhutan, Sri \\
$\begin{array}{l}\text { Lanka, Cambodia, Myanmar, Lao People's } \\
\text { Democratic Republic, India, Viet Nam }\end{array}$ & 6.0 & 3.0 \\
\hline $\begin{array}{l}\text { B: Maldives; Solomon Islands; Indonesia; Papua } \\
\text { New Guinea; Thailand; Macau, China; Bangladesh }\end{array}$ & 4.0 & 2.5 \\
\hline $\begin{array}{l}\text { C: Hong Kong, China; Taipei,China; Philippines; } \\
\text { Republic of Korea; Afghanistan; Pakistan; Nepal; }\end{array}$ & & \\
$\begin{array}{l}\text { Singapore; Azerbaijan; Georgia; Armenia; } \\
\text { Kazakhstan; Malaysia; Tajikistan; Turkmenistan; } \\
\text { Uzbekistan }\end{array}$ & 3.0 & 2.0 \\
\hline D: Japan, Brunei Darussalam, all others & & \\
\hline
\end{tabular}

GDP = gross domestic product.

Sources: OECD. http://www.oecd.org/eco/outlook/lookingto2060.htm; ADB http://www.iadb.org/intal/intalcdi/PE/2011/

09482.pdf; United States Department of Agriculture. http://www.ers.usda.gov/data-products/international -macroeconomic-data-set/

\section{B. Public Sector Finances}

Data on public sector finances are based on National Transfer Accounts (NTA), a new set of economic accounts which document economic flows to and from ages in a manner consistent with the UN System of National Accounts. Research teams in about 50 countries on six continents are currently collaborating in the construction of NTA. Accounts have been constructed for 11 Asian economies-Bangladesh; Cambodia; the PRC; India; Indonesia; Japan; the Philippines; the Republic of Korea; Taipei,China; Thailand; and Viet Nam.

The theoretical foundations of the accounts build on Lee (1994a, 1994b) and some details and preliminary results are reported in Lee, Lee, and Mason (2008); and Mason et al. (2009). The most recent and comprehensive treatment is Lee and Mason (2011). Methods are fully documented and explained in United Nation Population Division (2013b) and on the NTA website at www.ntaccounts.org

In NTA, transfer inflows refer to flows received by the beneficiaries of all public programs, which are used for projections of public spending. Transfer outflows refer to the flows from taxpayers who are funding the program, which include taxes and other sources of revenue. For example, if the government runs a deficit, then transfer outflows are equal to taxes, plus other sources of revenue that make up the difference: grants, net public asset income, and dissaving represented by the sale of public debt. In NTA, taxes provide the age pattern of all public transfer outflows, but not the macro controls. Instead, the macro controls are equal to public transfer inflows plus any net transfer of the program to the rest of the world (ROW) entities.

Public transfer outflows are assigned to taxpayers based on rules that are similar to those followed in generational accounting. It is constructed in two steps. First, age profiles of taxes and social contributions are constructed. Second, these age profiles are combined with information about how each type of government program is funded (the "source") to construct age profiles of public transfer outflows by purpose (Table 2). 
Public transfer inflows are public benefits, classified by purpose: education, health, pensions, and other public programs. This classification is consistent with the UN Classification of Functions of Government, but simplified to emphasize large inter-age transfers. These public transfer inflows provide the age pattern of government spending. Distinguishing the purpose of inflows is important for constructing age profiles. Transfer inflows for many public programs are assigned to the age group of the intended beneficiary of the public program in question using techniques described below. The inflows from public collective goods, e.g., national defense or diplomacy, public administration, and public safety programs are assigned equally among all members of the population, i.e., on a per capita basis.

Table 2: Mapping of IMF Government Finance Statistics, Revenue to Tax Profiles

\begin{tabular}{|c|c|}
\hline GFS Classification & NTA Tax Source \\
\hline \multicolumn{2}{|l|}{ Taxes } \\
\hline \multicolumn{2}{|l|}{ Taxes on income, profit, and capital gains } \\
\hline Payable by individuals & Labor and asset income \\
\hline Payable by corporations and other enterprise & Asset income \\
\hline Taxes on payroll and workforce & Labor income \\
\hline Taxes on property & Asset holding \\
\hline Taxes on goods and services & Consumption \\
\hline Taxes on international trade and transactions & Various \\
\hline Other Taxes & Various \\
\hline Social Contributions & Labor income \\
\hline \multicolumn{2}{|l|}{ Subsidies } \\
\hline To public corporations & Various \\
\hline To private enterprises & Various \\
\hline \multicolumn{2}{|l|}{ Grants } \\
\hline \multicolumn{2}{|l|}{ From foreign governments } \\
\hline Current & Rest of the world \\
\hline Capital & Exclude from NTA flow account \\
\hline \multicolumn{2}{|l|}{ From foreign governments } \\
\hline Current & Rest of the world \\
\hline Capital & Exclude from NTA flow account \\
\hline From other general government units & Zero for general government \\
\hline \multicolumn{2}{|l|}{ Other revenue } \\
\hline Property income & Not a public transfer (Asset income) \\
\hline Sales of goods and services & Other \\
\hline Fines, penalties, and forfeits & Other \\
\hline \multicolumn{2}{|l|}{ Voluntary transfers other than grants } \\
\hline Current & Other \\
\hline Capital & Exclude from NTA flow account \\
\hline Miscellaneous and unidentified revenue & Other \\
\hline
\end{tabular}

GFS = Government Finance Statistics, IMF = International Monetary Fund, NTA = National Transfer Accounts. Sources: UN Population Division (2013b). 
Public spending on social welfare is much lower in low-income Asian countries than in highincome countries in per capita terms, but also relative to standards of living. As incomes grow in the region, taxes and public spending will become increasingly important. Exactly how countries adjust to higher income is a matter of policy and will be determined by political decisions within each country.

We use age profiles of tax and public spending by age for Asian countries for which NTA profiles are available, as follows. All profiles are per capita flows to persons at each age expressed relative to the average per capita labor income of those aged 30-49. Thus, given a particular profile, per capita flows rise at the same rate as projected per capita labor income for prime age adults. In addition, we assume that as countries become members of higher income groups that they will experience additional changes in their fiscal profiles. Four model profiles, constructed for the varying levels of income shown in Table 1, are used to allow for the effects of income, as shown below in Table 3.

\section{Table 3: Model Profiles Based on Per Capita Income}

\begin{tabular}{cc}
\hline $\begin{array}{c}\text { Income Range } \\
\text { (Per capita GDP in 2005 prices) }\end{array}$ & Model Profiles \\
\hline Under $\$ 5,000$ & $\begin{array}{c}\text { Asian low-income countries. For tax: the PRC 2002, Cambodia 2009, and } \\
\text { Indonesia 2005. For education and health: India 2004, Indonesia 2005, the } \\
\text { Philippines 1999, the PRC 2002, Thailand 2004, and Viet Nam 2008. For } \\
\text { social protection: the PRC 2002, the Philippines 1999, and Thailand 2004. }\end{array}$ \\
\hline$\$ 5,000$ to 10,000 & Interpolated \\
\hline$\$ 10,000$ to 15,000 & Republic of Korea 2000 and Taipei,China 1998 for tax and expenditure \\
\hline$\$ 15,000$ to 20,000 & Interpolated \\
\hline$\$ 20,000$ to 30,000 & Interpolated \\
\hline$\$ 30,000$ to 35,000 & Japan 1994 \\
\hline$\$ 35,000$ or more & Japan 1999 and Japan 2004 \\
\hline
\end{tabular}

GDP = gross domestic product, PRC = People's Republic of China.

Source: National Transfer Accounts. www.ntaccounts.org (accessed 31 August 2015).

The profiles thus obtained for each income group are shown in Figures 4 and 5 . The level of spending and revenue rises relative to income as per capita income reaches higher levels.

In Figure 4, the age patterns of government spending are particularly visible for the older people due to the dramatic increase in their health expenditure. For low- and middle-income countries, the increase in spending on health care at older ages is less pronounced than for higherincome countries, where health care spending rises very sharply with age. ${ }^{2}$ All projections are scaled and adjusted proportionately to match the actual observed values of government expenditure in 2010 as a percentage of GDP for each country, provided by ADB. This guarantees that our projections depend on country-specific growth rate, age structure change, levels of tax revenue versus nontax revenue, the share of social welfare spending, and the level of debt financing.

2 Lee and Mason (2015) project government spending for education, health, and social protection, respectively. 


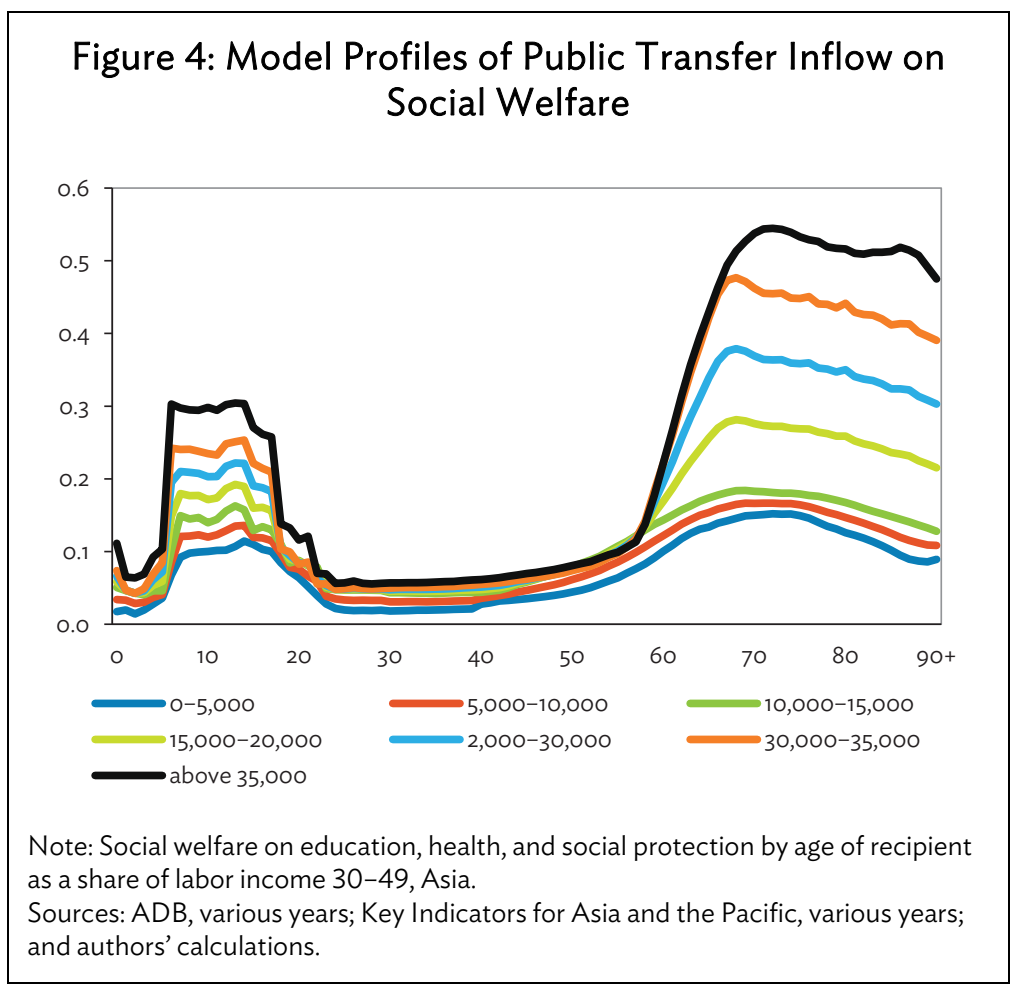

\section{Figure 5: Model Profiles of Public Transfer Outflow} by Age of Tax Payers

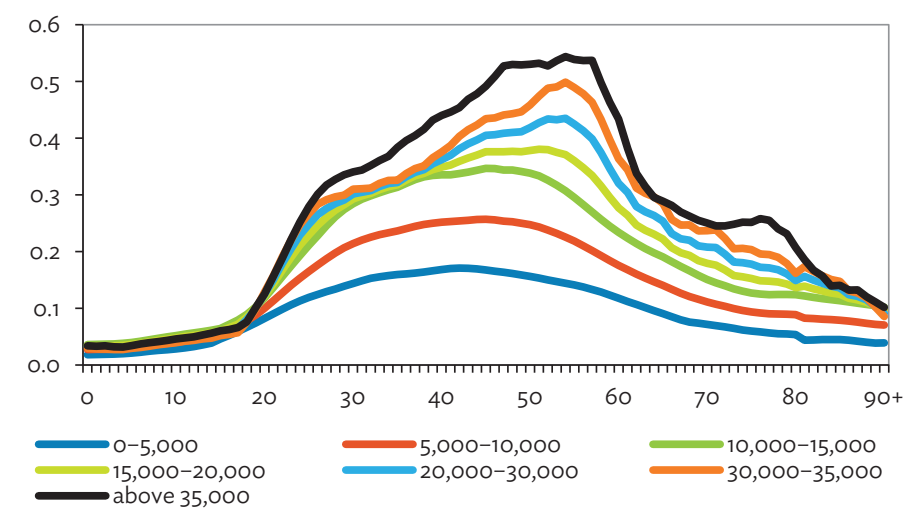

Note: Share of labor income 30-49, Asia.

Sources: ADB, various years; Key Indicators for Asia and the Pacific, various years; and authors' calculations.

Again, Figure 4 does not include the other public spending, which benefits everyone (i.e., allocated equally to the whole population) such as national defense. Nevertheless, other public spending is assumed to increase the same rate as per capita GDP and we calibrate the aggregate controls for whole countries at their 2010 values. Therefore, using the profiles, excluding the other public spending, which benefit everyone does not affect the results. Likewise, using the tax profile to estimate government revenue, including nontax revenue will not change our results since we assume that nontax revenue as a percent of GDP will not change over time. 


\section{FISCAL PROJECTIONS}

In this section, we present our projections for government expenditures, tax revenues, government revenues, and fiscal balance up to 2050 .

Actual values (1995-2010) and projections of government expenditure to 2050 are provided in Table 4. Populations are aging, which should push up the level of social welfare spending. In addition, higher levels of per capita income should push per capita spending on social welfare. For a few countries (see table notes), spending by all levels of government are included, but in most cases, the values refer to central government spending only.

\section{A. Expenditure}

On average, the increase amounts to a 3.3 percentage rise in the percentage of GDP spent on public expenditure. ${ }^{3}$ The simple average of developing Asian countries increases from $24.4 \%$ of GDP in 2010 to $27.7 \%$, if we exclude countries with missing data in any particular period. The rise in public expenditure is particularly dramatic in East Asia, with the average share of GDP rising from 16.9\% of GDP in 2010 to $27.5 \%$ of GDP in 2050 . In the PRC, the projected rise is from $22.4 \%$ to $33.9 \%$ of GDP, a projected increase of $51 \%$. This sharp increase reflects rapid aging combined with relatively high rates of economic growth. In the Republic of Korea, it will increase from 19.8\% in 2010 to 32.4\% in 2050, in large part due to population aging. In a number of other countries outside East Asia, public expenditures will also grow quite rapidly.

For a few countries, only a small increase is projected because projected economic growth and projected population aging are limited. Government expenditure in Bangladesh, India, and the Philippines are projected to reach $12.6 \%, 16.5 \%$, and $16.9 \%$ of GDP, respectively in 2050 . Note that spending in Singapore is quite low in 2050 (16.9\%), but its mandatory provident fund, the Central Provident Fund, is not included in the figures.

High public spending is not limited to Asia's higher-income countries. Several Central and West Asian countries (Armenia, Azerbaijan, Georgia, and the Kyrgyz Republic), South Asian countries (Bhutan and Maldives), and Timor-Leste have high levels projected for 2050 . These projections may be quite conservative. We only emphasize the kind of benefits which are affected by the age structure. Other public spending may also increase rapidly, but they are not considered here. Other public expenditure can only be assessed with more extensive data with detailed information on the different components of public spending.

3 The calculation excludes those with missing observations in any period. 
Table 4: Government Expenditure

(\% of GDP)

\begin{tabular}{|c|c|c|c|c|c|c|c|c|}
\hline & 1995 & 2000 & 2005 & 2010 & 2020 & 2030 & 2040 & 2050 \\
\hline \multicolumn{9}{|l|}{ Developing Member Economies ${ }^{a}$} \\
\hline Afghanistan & $\ldots$ & $\ldots$ & 16.5 & 20.6 & $\ldots$ & $\ldots$ & & $\ldots$ \\
\hline Armenia & 24.0 & 20.1 & 18.0 & 27.6 & 28.4 & 29.7 & 30.3 & 32.1 \\
\hline Azerbaijan & 20.1 & 16.2 & 16.8 & 27.6 & 27.7 & 30.4 & 30.6 & 31.1 \\
\hline Georgia & & 16.3 & 26.6 & 34.0 & 34.7 & 35.8 & 35.8 & 36.2 \\
\hline Kazakhstan & 25.7 & 22.2 & 25.6 & 22.0 & $\ldots$ & $\ldots$ & $\ldots$ & $\ldots$ \\
\hline Kyrgyz Republic & 27.8 & 18.0 & 20.4 & 31.2 & 31.3 & 32.8 & 32.8 & 33.4 \\
\hline Pakistan & 23.0 & 18.9 & 16.8 & 20.2 & $\ldots$ & $\ldots$ & $\ldots$ & $\ldots$ \\
\hline Tajikistan & 17.4 & 14.7 & 19.4 & 25.1 & 25.3 & 26.1 & 26.2 & 26.7 \\
\hline Turkmenistan & 20.1 & 23.9 & 19.7 & 14.1 & $\ldots$ & $\ldots$ & $\ldots$ & $\ldots$ \\
\hline Uzbekistan & 32.6 & 28.9 & 22.5 & 21.5 & $\ldots$ & $\ldots$ & $\ldots$ & $\ldots$ \\
\hline \multicolumn{9}{|l|}{ East Asia } \\
\hline China, People's Republic of ${ }^{b}$ & $\ldots$ & 16.3 & 18.3 & 22.4 & 25.2 & 26.1 & 29.3 & 33.9 \\
\hline Hong Kong, China & 16.4 & 17.4 & 16.5 & 17.0 & 18.7 & 20.6 & 21.4 & 21.8 \\
\hline Korea, Rep. of & 15.3 & 17.2 & 20.1 & 19.8 & 20.9 & 28.2 & 30.9 & 32.4 \\
\hline Mongolia & 19.7 & 30.0 & 22.7 & 33.8 & $\ldots$ & $\ldots$ & $\ldots$ & $\ldots$ \\
\hline Taipei,China & 14.3 & 22.6 & 15.1 & 13.9 & 16.6 & 21.0 & 25.9 & 28.2 \\
\hline \multicolumn{9}{|l|}{ South Asia } \\
\hline Bangladesh & 14.4 & 14.5 & 15.0 & 12.7 & 12.5 & 12.5 & 12.5 & 12.6 \\
\hline Bhutan & 37.2 & 42.2 & 35.4 & 35.6 & 34.9 & 38.5 & 39.0 & 43.6 \\
\hline India & 14.1 & 15.5 & 13.7 & 15.4 & 15.3 & 15.2 & 15.3 & 16.5 \\
\hline Maldives & 36.6 & 37.3 & 45.5 & 40.3 & 39.6 & 44.0 & 44.4 & 45.5 \\
\hline Nepal & 16.6 & 16.3 & 15.3 & 21.8 & 21.5 & 21.1 & 21.2 & 21.3 \\
\hline Sri Lanka & 29.6 & 25.0 & 23.8 & 22.1 & 22.5 & 24.5 & 24.7 & 24.8 \\
\hline \multicolumn{9}{|l|}{ Southeast Asia } \\
\hline Brunei Darussalam & 66.0 & 40.6 & 32.1 & 36.9 & 37.2 & 38.6 & 39.5 & 41.4 \\
\hline Cambodia & 14.8 & 14.8 & 13.2 & 21.3 & 21.2 & 21.4 & 21.4 & 21.5 \\
\hline Indonesia & 14.7 & 15.8 & 18.4 & 16.2 & 16.4 & 16.5 & 16.8 & 18.1 \\
\hline Lao PDR & 26.7 & 20.8 & 18.4 & 24.2 & 24.2 & 24.3 & 24.5 & 24.8 \\
\hline Malaysia & 22.1 & 22.9 & 23.0 & 25.5 & 24.6 & 26.4 & 26.4 & 28.6 \\
\hline Myanmar & 9.8 & 3.5 & $\ldots$ & 18.9 & $\ldots$ & $\ldots$ & $\ldots$ & $\ldots$ \\
\hline Philippines & 18.2 & 18.1 & 16.9 & 16.9 & 16.9 & 16.8 & 16.9 & 16.9 \\
\hline Singapore & 15.6 & 18.5 & 14.4 & 14.8 & 14.5 & 14.7 & 14.9 & 14.8 \\
\hline Thailand & 15.3 & 16.8 & 17.3 & 19.2 & 19.2 & 22.1 & 22.6 & 26.1 \\
\hline Viet Nam ${ }^{b}$ & 23.8 & 22.6 & 25.1 & 27.2 & $\ldots$ & $\ldots$ & $\ldots$ & $\ldots$ \\
\hline \multicolumn{9}{|l|}{ The Pacific } \\
\hline Fiji & 26.0 & 28.5 & 27.3 & 27.7 & 27.7 & 27.7 & 27.5 & 29.9 \\
\hline Micronesia, Fed. States of & 77.0 & 67.2 & 59.3 & 67.7 & $\ldots$ & $\ldots$ & $\ldots$ & $\ldots$ \\
\hline Papua New Guinea & 28.3 & 32.9 & 35.2 & 30.7 & 30.6 & 30.4 & 30.3 & 30.2 \\
\hline Samoa & 40.5 & 31.2 & 32.7 & 34.7 & 35.1 & 35.0 & 35.0 & 35.1 \\
\hline Solomon Islands & 32.3 & 31.6 & 34.6 & 39.7 & $\ldots$ & $\ldots$ & $\ldots$ & $\ldots$ \\
\hline Timor-Leste & & $\ldots$ & 5.7 & 18.4 & 18.3 & 18.1 & 18.1 & 18.6 \\
\hline Tonga & 26.3 & 22.2 & 21.2 & 28.0 & 28.2 & 28.0 & 28.1 & 28.3 \\
\hline \multirow[t]{2}{*}{ Vanuatu } & 29.3 & 26.0 & 18.4 & 26.3 & 26.3 & 26.0 & 25.9 & 25.9 \\
\hline & 25.4 & 23.4 & 22.7 & 25.4 & 24.6 & 26.0 & 26.5 & 27.7 \\
\hline Developed Member Economy ${ }^{a}$ & & & & 25.5 & & & & 27.6 \\
\hline Japan & 16.1 & 18.3 & 16.0 & 18.0 & 20.5 & 21.8 & 23.9 & 24.8 \\
\hline
\end{tabular}

... = data not available, GDP = gross domestic product, Lao PDR = Lao People's Democratic Republic.

a Data refer to central government, except for Bangladesh, Georgia, Kiribati, the Kyrgyz Republic, Pakistan, and Tajikistan, where data refer to consolidated government or general government.

b Expenditure includes local government expenditure.

Source: ADB and authors' calculations. 
Table 5: Government Tax Revenue

(\% of GDP)

\begin{tabular}{|c|c|c|c|c|c|c|c|c|}
\hline & 1995 & 2000 & 2005 & 2010 & 2020 & 2030 & 2040 & 2050 \\
\hline \multicolumn{9}{|c|}{$\begin{array}{l}\text { Developing Member Economies } \\
\text { Central and West Asia }\end{array}$} \\
\hline Armenia & 10.6 & 14.8 & 14.3 & 20.2 & 20.8 & 21.0 & 20.8 & 21.3 \\
\hline Azerbaijan & 10.8 & 12.2 & 14.0 & 12.4 & 12.8 & 19.2 & 19.3 & 18.9 \\
\hline Georgia & & 14.6 & 20.8 & 23.5 & 23.2 & 22.9 & 22.5 & 22.2 \\
\hline Kazakhstan & 15.8 & 20.2 & 26.3 & 13.4 & 19.8 & 19.9 & 20.1 & 26.7 \\
\hline Kyrgyz Republic & 15.1 & 11.7 & 16.2 & 17.9 & 18.1 & 18.4 & 19.0 & 19.1 \\
\hline Pakistan & 13.8 & 10.6 & 10.1 & 10.1 & 10.9 & 11.5 & 11.9 & 12.2 \\
\hline Tajikistan & 8.4 & 13.1 & 16.5 & 18.0 & 18.4 & 18.9 & 19.6 & 19.8 \\
\hline Turkmenistan & & 23.0 & & & & & & \\
\hline Uzbekistan & 27.8 & $\ldots$ & 21.5 & 20.4 & 21.7 & 22.6 & 23.0 & 23.0 \\
\hline \multicolumn{9}{|l|}{ East Asia } \\
\hline China, People's Rep. of & 9.9 & 12.7 & 15.6 & 18.2 & 27.3 & 26.8 & 34.9 & 37.3 \\
\hline Hong Kong, China & 11.2 & 9.7 & 12.3 & 13.6 & 15.2 & 14.5 & 13.9 & 13.3 \\
\hline Korea, Rep. of & 15.2 & 17.0 & 13.9 & 14.0 & 14.4 & 17.0 & 16.2 & 15.6 \\
\hline Mongolia & 16.2 & 21.3 & 22.8 & 31.9 & 32.7 & 33.1 & 33.3 & \\
\hline Taipei,China & 10.3 & 13.3 & 9.1 & 8.0 & 8.9 & 9.6 & 10.4 & 9.9 \\
\hline \multicolumn{9}{|l|}{ South Asia } \\
\hline Bangladesh & 7.9 & 6.8 & 8.6 & 7.8 & 8.4 & 8.8 & 9.0 & 8.9 \\
\hline Bhutan & 6.6 & 10.0 & 9.4 & 13.3 & 14.5 & 22.4 & 22.7 & 29.7 \\
\hline India & 6.9 & 6.5 & 7.3 & 7.3 & 7.6 & 7.9 & 8.0 & 12.0 \\
\hline Maldives & 13.6 & 13.8 & 13.6 & 10.7 & 11.6 & 18.0 & 18.5 & 18.2 \\
\hline Nepal & 8.4 & 8.1 & 9.2 & 13.4 & 14.7 & 15.8 & 16.4 & 16.6 \\
\hline Sri Lanka & 17.9 & 14.2 & 13.7 & 12.9 & 12.8 & 19.0 & 19.1 & 19.1 \\
\hline \multicolumn{9}{|l|}{ Southeast Asia } \\
\hline Brunei Darussalam & 18.4 & 23.4 & 33.1 & & & & & \\
\hline Cambodia & 5.3 & 7.3 & 7.7 & 10.7 & 11.2 & 11.6 & 11.9 & 11.8 \\
\hline Indonesia & 16.0 & 8.3 & 12.5 & 11.2 & 11.6 & 11.9 & 11.9 & 17.8 \\
\hline Lao PDR & 9.4 & 10.6 & 9.7 & 13.5 & 14.6 & 15.6 & 16.3 & 16.6 \\
\hline Malaysia & 18.7 & 13.2 & 14.8 & 13.7 & 14.6 & 19.9 & 20.1 & 21.9 \\
\hline Myanmar & 3.7 & 2.0 & & 3.2 & 3.4 & 3.4 & 3.4 & 3.5 \\
\hline Philippines & 16.3 & 12.8 & 12.4 & 12.1 & 12.7 & 13.1 & 13.5 & 13.7 \\
\hline Singapore & 15.9 & 15.1 & 11.5 & 13.2 & 13.1 & 12.7 & 12.3 & 12.0 \\
\hline Thailand & 16.4 & 12.8 & 15.3 & 14.6 & 14.8 & 21.7 & 20.9 & 27.1 \\
\hline Viet $\mathrm{Nam}^{\mathrm{b}}$ & 19.1 & 18.0 & 21.0 & 22.4 & 23.5 & 23.8 & 23.5 & 22.7 \\
\hline \multicolumn{9}{|l|}{ The Pacific } \\
\hline Fiji & 21.9 & 19.9 & 21.0 & 21.6 & 21.8 & 22.1 & 22.4 & 33.5 \\
\hline Micronesia, Fed. States of & 9.5 & 11.9 & 11.7 & 12.0 & 12.9 & 13.6 & 14.3 & 14.8 \\
\hline Papua New Guinea & 19.5 & 23.8 & 24.8 & 24.4 & 25.4 & 26.5 & 27.4 & 28.1 \\
\hline Samoa & 22.5 & 20.6 & 20.6 & 24.2 & 24.5 & 25.1 & 25.8 & 26.6 \\
\hline Solomon Islands & 21.4 & 19.1 & 24.3 & 34.0 & 35.3 & 36.9 & 38.3 & 39.5 \\
\hline Timor-Leste & & & 1.5 & 1.2 & 1.2 & 1.3 & 1.4 & 1.5 \\
\hline Tonga & 13.4 & 15.8 & 19.2 & 16.1 & 16.4 & 17.1 & 17.5 & 18.0 \\
\hline \multirow[t]{2}{*}{ Vanuatu } & 19.6 & 15.7 & 16.4 & 16.0 & 16.9 & 17.6 & 18.2 & 18.5 \\
\hline & 13.9 & 13.9 & 15.0 & 15.1 & 16.1 & 17.6 & 18.1 & 19.0 \\
\hline \multicolumn{9}{|c|}{ Developed Member Economy } \\
\hline Japan & 10.7 & 10.4 & 10.2 & 8.9 & 8.8 & 8.6 & 8.3 & 8.1 \\
\hline
\end{tabular}

... = data not available, GDP = gross domestic product, Lao PDR = Lao People's Democratic Republic.

a Data refer to central government, except for Bangladesh, Georgia, Kiribati, the Kyrgyz Republic, Pakistan, and Tajikistan, where data refer to consolidated government or general government.

b Tax revenue includes local government tax revenue.

Source: ADB and authors' calculations. 
Table 6: Government Revenue (\% of GDP)

\begin{tabular}{|c|c|c|c|c|c|c|c|c|}
\hline & 1995 & 2000 & 2005 & 2010 & 2020 & 2030 & 2040 & 2050 \\
\hline \multicolumn{9}{|c|}{$\begin{array}{l}\text { Developing Member Economies }{ }^{a} \\
\text { Central and West Asia }\end{array}$} \\
\hline Afghanistan & $\ldots$ & $\ldots$ & 6.9 & 10.8 & 11.7 & 12.9 & 13.9 & 14.6 \\
\hline Armenia & 14.4 & 15.9 & 16.2 & 21.7 & 22.3 & 22.5 & 22.3 & 22.7 \\
\hline Azerbaijan & 11.8 & 14.7 & 16.3 & 26.8 & 27.2 & 33.6 & 33.7 & 33.3 \\
\hline Georgia & $\ldots$ & 15.5 & 27.1 & 27.1 & 26.8 & 26.4 & 26.1 & 25.8 \\
\hline Kazakhstan & 19.6 & 22.9 & 27.6 & 14.2 & 20.5 & 20.6 & 20.9 & 27.4 \\
\hline Kyrgyz Republic & 16.7 & 14.2 & 19.8 & 23.1 & 23.4 & 23.7 & 24.3 & 24.4 \\
\hline Pakistan & 17.3 & 13.4 & 13.8 & 14.0 & 14.8 & 15.4 & 15.8 & 16.1 \\
\hline Tajikistan & 10.0 & 14.1 & 19.2 & 19.3 & 19.7 & 20.2 & 20.9 & 21.2 \\
\hline Turkmenistan & 20.5 & 23.5 & 20.5 & 16.1 & $\ldots$ & & $\ldots$ & \\
\hline Uzbekistan & 29.7 & 28.0 & 22.6 & 21.8 & 23.1 & 23.9 & 24.4 & 24.3 \\
\hline \multicolumn{9}{|l|}{ East Asia } \\
\hline China, People's Rep. of ${ }^{b}$ & 10.3 & 13.5 & 17.1 & 20.7 & 29.8 & 29.3 & 37.4 & 39.8 \\
\hline Hong Kong, China & 16.1 & 16.8 & 17.5 & 21.2 & 22.8 & 22.1 & 21.5 & 20.9 \\
\hline Korea, Rep. of & 17.8 & 21.4 & 20.8 & 21.4 & 21.8 & 24.3 & 23.6 & 22.9 \\
\hline Mongolia & 20.8 & 28.3 & 27.4 & 36.7 & 37.4 & 37.8 & 38.0 & $\ldots$ \\
\hline Taipei,China & 13.3 & 18.0 & 14.8 & 11.1 & 12.1 & 12.8 & 13.6 & 13.1 \\
\hline \multicolumn{9}{|l|}{ South Asia } \\
\hline Bangladesh & 9.8 & 8.5 & 10.6 & 9.5 & 10.1 & 10.5 & 10.6 & 10.6 \\
\hline Bhutan & 19.1 & 23.2 & 17.0 & 27.4 & 28.6 & 36.5 & 36.8 & 43.8 \\
\hline India & 9.9 & 9.8 & 9.7 & 10.6 & 10.9 & 11.1 & 11.3 & 15.2 \\
\hline Maldives & 25.8 & 30.0 & 29.8 & 23.4 & 24.3 & 30.7 & 31.2 & 30.9 \\
\hline Nepal & 10.4 & 10.5 & 11.9 & 15.1 & 16.3 & 17.5 & 18.1 & 18.2 \\
\hline Sri Lanka & 20.6 & 16.4 & 15.5 & 14.6 & 14.5 & 20.7 & 20.7 & 20.7 \\
\hline \multicolumn{9}{|l|}{ Southeast Asia } \\
\hline Brunei Darussalam & 36.5 & 49.1 & 53.2 & 54.3 & $\ldots$ & & $\ldots$ & \\
\hline Cambodia & 7.6 & 10.0 & 10.6 & 13.2 & 13.8 & 14.2 & 14.4 & 14.4 \\
\hline Indonesia & 17.7 & 14.7 & 17.8 & 15.4 & 15.8 & 16.0 & 16.1 & 22.0 \\
\hline Lao PDR & 11.1 & 13.1 & 11.7 & 15.3 & 16.4 & 17.4 & 18.2 & 18.5 \\
\hline Malaysia & 22.9 & 17.4 & 19.6 & 20.0 & 20.9 & 26.2 & 26.4 & 28.1 \\
\hline Myanmar & 6.5 & 4.2 & $\ldots$ & 14.2 & 14.4 & 14.4 & 14.4 & 14.5 \\
\hline Philippines & 18.9 & 14.3 & 14.4 & 13.4 & 14.0 & 14.4 & 14.8 & 15.0 \\
\hline Singapore & 34.8 & 29.8 & 20.7 & 22.5 & 22.4 & 22.0 & 21.6 & 21.3 \\
\hline Thailand & 18.1 & 14.7 & 17.4 & 16.8 & 17.0 & 23.9 & 23.1 & 29.3 \\
\hline Viet Nam ${ }^{\mathrm{b}}$ & 21.9 & 20.1 & 25.7 & 26.7 & 27.8 & 28.1 & 27.8 & 27.0 \\
\hline \multicolumn{9}{|l|}{ The Pacific } \\
\hline Fiji & 25.5 & 25.4 & 23.9 & 25.4 & 25.5 & 25.8 & 26.1 & 37.2 \\
\hline Micronesia, Fed. States of & 26.4 & 22.5 & 20.8 & 21.8 & 22.7 & 23.5 & 24.2 & 24.6 \\
\hline Papua New Guinea & 24.0 & 25.7 & 26.8 & 26.1 & 27.2 & 28.2 & 29.1 & 29.8 \\
\hline Samoa & 29.9 & 25.6 & 24.0 & 27.3 & 27.5 & 28.2 & 28.9 & 29.7 \\
\hline Solomon Islands & 27.7 & 21.6 & 26.7 & 37.0 & 38.2 & 39.9 & 41.3 & 42.5 \\
\hline Timor-Leste & $\ldots$ & $\ldots$ & 9.7 & 22.0 & 22.0 & 22.1 & 22.2 & 22.3 \\
\hline Tonga & 25.6 & 21.1 & 22.8 & 20.1 & 20.5 & 21.2 & 21.6 & 22.1 \\
\hline \multirow[t]{2}{*}{ Vanuatu } & 24.2 & 18.7 & 18.5 & 17.6 & 18.5 & 19.2 & 19.8 & 20.1 \\
\hline & 19.1 & 19.1 & 19.7 & 21.0 & 21.2 & 22.7 & 23.2 & 24.1 \\
\hline \multicolumn{9}{|c|}{ Developed Member Economy ${ }^{a}$} \\
\hline Japan & 12.2 & 12.0 & 11.9 & 11.2 & 11.1 & 11.0 & 10.6 & 10.4 \\
\hline
\end{tabular}

... = data not available, GDP = gross domestic product, Lao PDR = Lao People's Democratic Republic.

a Data refer to central government, except for Bangladesh, Georgia, Kiribati, the Kyrgyz Republic, Pakistan, and Tajikistan, where data refer to consolidated government or general government.

b Government revenue includes local government revenue.

Source: ADB and authors' calculations. 
Table 7: Fiscal Balance (\% of GDP)

\begin{tabular}{|c|c|c|c|c|c|c|c|c|}
\hline & 1995 & 2000 & 2005 & 2010 & 2020 & 2030 & 2040 & 2050 \\
\hline \multicolumn{9}{|c|}{ Developing Member Economies $^{a}$} \\
\hline \multicolumn{9}{|c|}{ Central and West Asia } \\
\hline Afghanistan & $\ldots$ & $\ldots$ & -4.5 & 2.5 & $\ldots$ & $\ldots$ & $\ldots$ & $\ldots$ \\
\hline Armenia & -5.9 & -4.9 & -1.9 & -5.0 & -4.8 & -1.0 & -1.2 & -2.1 \\
\hline Azerbaijan & -5.2 & -1.0 & -0.7 & -0.9 & -1.1 & -2.1 & -3.0 & -4.3 \\
\hline Georgia & $\ldots$ & -1.3 & 1.2 & -5.6 & -6.6 & -8.1 & -8.4 & -9.1 \\
\hline Kazakhstan & -4.0 & -0.1 & 0.6 & -2.4 & $\ldots$ & $\ldots$ & $\ldots$ & $\ldots$ \\
\hline Kyrgyz Republic & -11.5 & -2.2 & 0.2 & -4.9 & -4.7 & -5.9 & -5.3 & -5.8 \\
\hline Pakistan & -5.6 & -5.4 & -3.0 & -5.9 & $\ldots$ & $\ldots$ & $\ldots$ & $\ldots$ \\
\hline Tajikistan & -7.4 & -0.6 & 0.2 & -7.1 & -6.9 & -7.2 & -6.6 & -6.0 \\
\hline Turkmenistan & 0.4 & -0.3 & 0.8 & 2.0 & $\ldots$ & $\ldots$ & $\ldots$ & $\ldots$ \\
\hline Uzbekistan & -2.9 & -1.0 & 0.1 & 0.3 & $\ldots$ & $\ldots$ & $\ldots$ & $\ldots$ \\
\hline \multicolumn{9}{|l|}{ East Asia } \\
\hline China, People's Rep. of ${ }^{b}$ & $\ldots$ & -2.8 & -1.2 & -1.7 & 4.6 & 3.2 & 8.2 & 6.0 \\
\hline Hong Kong, China & -0.3 & -0.6 & 1.0 & 4.2 & 4.1 & 1.5 & 0.1 & -1.0 \\
\hline Korea, Rep. of & 0.3 & 1.0 & 0.4 & 1.3 & 0.6 & -4.1 & -7.6 & -9.7 \\
\hline Mongolia & -1.3 & -6.4 & 2.4 & 0.5 & $\ldots$ & $\ldots$ & $\ldots$ & $\ldots$ \\
\hline Taipei,China & -1.0 & -4.5 & -0.3 & -2.8 & -4.5 & -8.2 & -12.4 & -15.1 \\
\hline \multicolumn{9}{|l|}{ South Asia } \\
\hline Bangladesh & -2.2 & -4.5 & -3.7 & -2.8 & -2.0 & -1.6 & -1.5 & -1.6 \\
\hline Bhutan & 0.1 & -3.9 & -6.6 & 1.5 & 3.5 & 7.8 & 7.6 & 10.0 \\
\hline India & -4.2 & -5.7 & -4.0 & -4.8 & -3.2 & -1.2 & -1.2 & -2.6 \\
\hline Maldives & -6.4 & -4.4 & -8.2 & -15.6 & -14.1 & -12.6 & -12.0 & -12.0 \\
\hline Nepal & -4.5 & -4.3 & -2.4 & -3.5 & -3.9 & 0.2 & 0.1 & -0.0 \\
\hline Sri Lanka & -8.8 & -9.3 & -7.0 & -8.0 & -7.5 & -7.3 & -7.1 & -4.4 \\
\hline \multicolumn{9}{|l|}{ Southeast Asia } \\
\hline Brunei Darussalam & 15.1 & 10.9 & 21.1 & 17.3 & $\ldots$ & $\ldots$ & $\ldots$ & $\ldots$ \\
\hline Cambodia & -7.2 & -2.1 & -0.7 & -3.2 & -3.0 & -2.9 & -3.1 & 1.4 \\
\hline Indonesia & 3.0 & -1.1 & -0.5 & -0.7 & 0.4 & 1.2 & 1.8 & 1.9 \\
\hline Lao PDR & -12.9 & -4.6 & -4.5 & -2.2 & -0.5 & 3.0 & 3.2 & 2.7 \\
\hline Malaysia & 0.8 & -5.5 & -3.4 & -5.4 & $\ldots$ & $\ldots$ & $\ldots$ & $\ldots$ \\
\hline Myanmar & -3.2 & 0.7 & $\ldots$ & -4.6 & -3.9 & -3.7 & -3.5 & -3.6 \\
\hline Philippines & 0.6 & -3.7 & -2.6 & -3.5 & -2.9 & -2.4 & -2.1 & -1.9 \\
\hline Singapore & 14.0 & 9.9 & 6.3 & 7.7 & 7.9 & 7.3 & 6.7 & 6.4 \\
\hline Thailand & 2.6 & -2.8 & 0.1 & -2.4 & $\ldots$ & $\ldots$ & $\ldots$ & $\ldots$ \\
\hline Viet Namb & -1.3 & -4.3 & -1.0 & -2.1 & -1.9 & 2.1 & 0.8 & 3.6 \\
\hline \multicolumn{9}{|l|}{ The Pacific } \\
\hline Fiji & -0.3 & -3.1 & -3.3 & -2.2 & $\ldots$ & $\ldots$ & $\ldots$ & $\ldots$ \\
\hline Micronesia, Fed. States of & -0.4 & -3.5 & -4.9 & 0.5 & 0.4 & 1.1 & 1.9 & 2.6 \\
\hline Papua New Guinea & -0.5 & -2.0 & 0.1 & 0.7 & $\ldots$ & $\ldots$ & $\ldots$ & $\ldots$ \\
\hline Samoa & -7.2 & -0.7 & 0.3 & -7.4 & -6.6 & -5.6 & -5.0 & -4.6 \\
\hline Solomon Islands & -4.6 & -0.6 & -0.9 & 8.3 & 8.4 & 8.7 & 9.2 & 17.8 \\
\hline Timor-Leste & $\ldots$ & $\ldots$ & 4.0 & 3.5 & 3.6 & 3.9 & 4.0 & 3.6 \\
\hline Tonga & 1.0 & -0.3 & 3.0 & -2.7 & -2.6 & -1.7 & -1.4 & -1.1 \\
\hline \multirow[t]{2}{*}{ Vanuatu } & -2.7 & -6.2 & 2.9 & -2.0 & -0.9 & 0.4 & 1.3 & 2.2 \\
\hline & -2.1 & -2.1 & -0.6 & -1.5 & -1.8 & -1.3 & -1.4 & -1.1 \\
\hline \multicolumn{9}{|c|}{ Developed Member Economy ${ }^{a}$} \\
\hline Japan & -3.9 & -6.3 & -4.1 & -6.7 & -9.4 & -10.9 & -13.3 & -14.4 \\
\hline
\end{tabular}

$\ldots=$ data not available, GDP = gross domestic product, Lao PDR = Lao People's Democratic Republic.

a Data refer to central government, except for Bangladesh, Georgia, Kiribati, the Kyrgyz Republic, Pakistan, and Tajikistan, where data refer to consolidated government or general government.

b Fiscal balance includes local government balance.

Source: ADB and authors' calculations. 


\section{B. Revenues and Fiscal Balance}

Estimates of tax revenue and government revenue as a percentage of GDP for selected economies up to 2050 are presented in Tables 5 and 6. Again, for a few countries (see table notes) revenue at all levels of government are included, but in most economies, the values refer to central government revenue only. Tax revenues average $15.2 \%$ of GDP (simple average of country values) in Asia. The average figure is projected to increase to $20.2 \%$ of GDP by 2050 , ranging between 1.5 and $39.5 \%$ of GDP.

The projected increase in revenue is driven by an increase in income level, and in some developing economies by increase in working-age population as well. Since we assumed that the share of nontax revenue as a percent of GDP will not change over time, the percentage change of tax revenue over time is the same as the percentage change of government revenue.

The importance of tax revenue, currently and in the future, varies considerably from economy to economy. Very large increase are projected for the PRC, where tax revenue as a share of GDP soared from $9.9 \%$ in 1995 to $18.2 \%$ in 2010, and it is projected to further increase to $37.3 \%$ until 2050, an increase of $105 \%$ for the next 40 years. But for the Republic of Korea and Taipei,China, tax revenues increase very little since the negative effect of population aging partially offsets the positive effects of growth. High levels of government revenues are not limited to East Asian economies. Several Central and West Asian countries (Armenia, Georgia, and Uzbekistan), South Asian countries (Bhutan and Maldives), and many countries in the Pacific have high levels of government revenue. Only Japan (central government) will experience a decline in tax revenue as a share of GDP due to shrinking working-age population.

Some countries rely much more on nontax revenues for government spending. Timor-Leste is an extreme case where the tax revenue accounts for only 1.5\% of GDP in 2010, even though government revenue is $22 \%$ of GDP in 2010. This is because foreign aid makes up the lion's share of the government budget. Another extreme case is Brunei Darussalam, where the difference between tax revenue and government revenue is about 20 percentage points as a share of GDP in 2005 . The nontax revenue is revenue from petroleum and natural gas sales. Mongolia is another significant outlier. Projections for these countries are not realistic and hence some estimates are dropped from our analysis.

Fiscal balance is the government's income from tax and other revenues, including the proceeds of assets sold, minus government spending. When the balance is negative, the government has a fiscal deficit. When the balance is positive, the government has a fiscal surplus. The projected fiscal balance is calculated as the difference between the projected increase in tax revenue and projected spending. The PRC and Bhutan show the most dramatic improvement in fiscal balance between 2010 and 2050.

However, our projections for revenues as well as fiscal balance should be interpreted with extreme caution. In contrast to our spending projections, our revenue projections are not conservative. In the real world, raising taxes would be more difficult than raising government expenditure. This is especially true for rapidly growing countries, i.e., country group A in our model (Mongolia, the PRC, Bhutan, Sri Lanka, Cambodia, Myanmar, the Lao People's Democratic Republic, India, and Viet Nam). As expected, our results predict fiscal improvement for these economies (Table 7). For example, the PRC recorded a fiscal deficit of $1.7 \%$ in 2010, but our projection shows a fiscal surplus of $6 \%$ in 2050. The same is true for Bhutan, which recorded a fiscal surplus of $1.5 \%$ in 2010 . The surplus is projected to increase further to $10 \%$ in 2050, the highest level among Asian economies. 
Figures 6 and 7 present the average of the actual and projected government expenditure, government revenue, tax revenue, and fiscal balance as a percent of GDP. These are unweighted simple average of developing Asian countries, which is limited to all countries for which we have estimates and projections for 1995-2050. The simple average shows that on average, revenues tend to rise faster than expenditures in our model. As a result, the fiscal deficit declines over time.
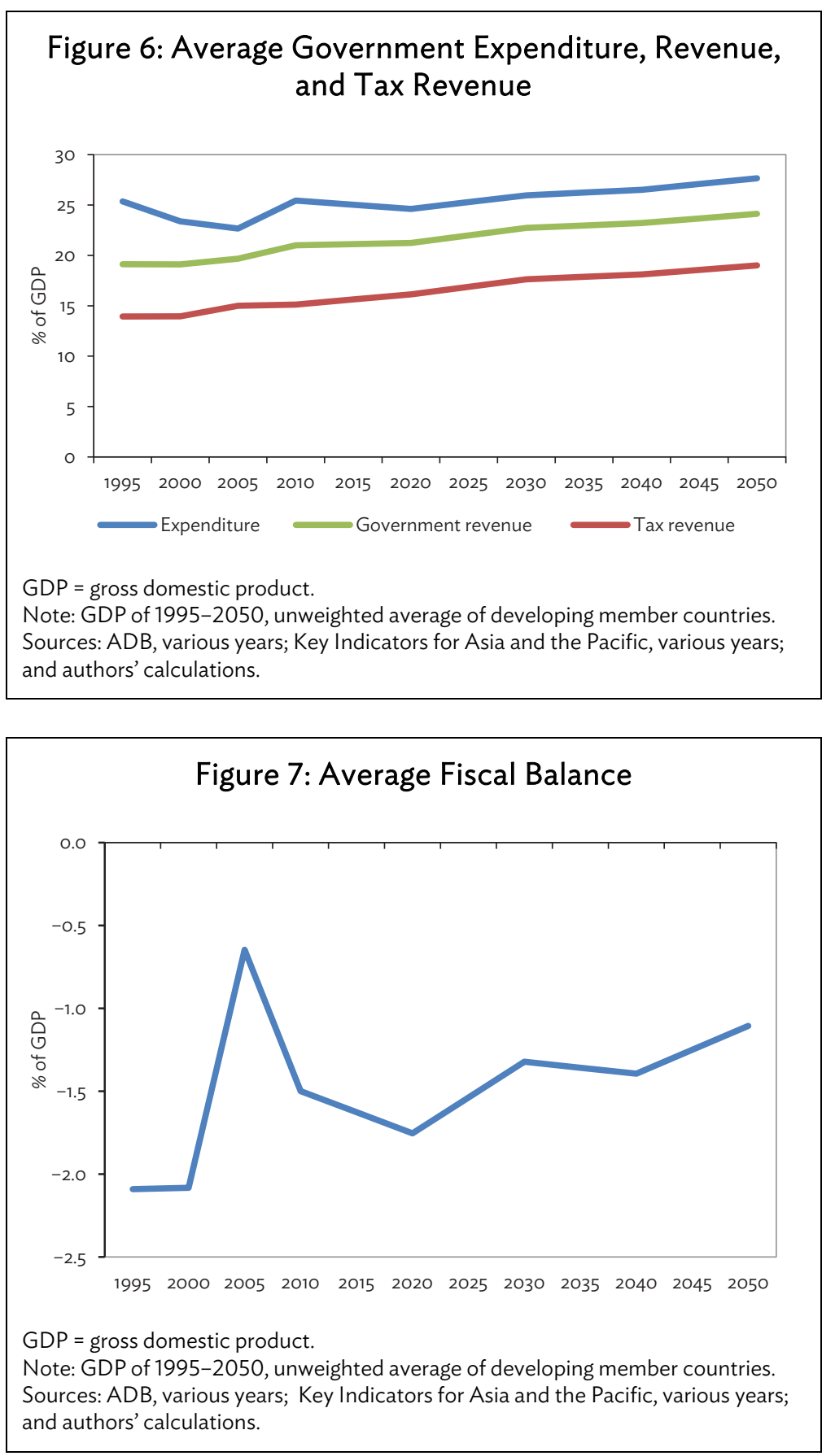
In fact, as economies anticipate or experience the effects of changes in their population age structure, they are likely to adjust taxes or benefits if they are concerned about the growth of the government. To address this issue, an alternative estimate based on the assumption of status quo is presented in the appendix tables (Tables A.1 and A.2). The status quo scenario projects tax revenues as a percent of GDP assuming that all countries maintain the fiscal balance of 2010 until 2050. The appendix Table A.1 shows that the tax revenue as a percentage of GDP for the PRC increases to $29.7 \%$ in 2050 instead of $37.3 \%$, as in the original scenario. The opposite is true for the Republic of Korea or Taipei,China. Tax revenues for the Republic of Korea are projected to increase to $26.6 \%$ in 2050 (instead of $15.6 \%$ ) if fiscal balance is held constant. For Taipei,China, tax revenues rise to $22.3 \%$, instead of $9.9 \%$.

\section{DECOMPOSITION RESULTS}

The projections of tax revenue, public sector spending, and fiscal balance are driven by changes in the level of taxation and spending and changes in age structure. Although the level of taxation and spending have been indexed to per capita income, it would be a mistake to interpret this as a causal relation between income and the level of spending. Instead correlates of income may account for some or all of the changes in the level of spending.

The analysis, presented in Tables $8-10$, is based on a simple decomposition procedure. The value in the first column of numbers, the 2010 value, is the actual share of GDP in 2010. The second column is the projected change in the percent of GDP between 2010 and 2050. The third column reports the effect of changing age structure calculated by holding the level of tax, spending, and fiscal balance at their 2010 levels, using population age structures for 2010 and 2050 . The next column reports the difference between the total change and the change due to age structure as the amount due to age-specific changes in the level of tax and spending. The interaction between changes in the level of taxes, benefits, fiscal balance, and age structure are reported in the following column. The final three columns in the table report the change due to age structure, age-specific level of spending, and interaction between the two as a percentage of the 2010 value (Tables 8 and 9) or as a percentage of percentage change from 2010 value (Table 10). These values control for the large effect of the initial level of spending and allow us to focus our attention on the importance of age structure and agespecific level of spending.

For government expenditures, the effects of changing age structure and changing levels of agespecific spending mutually reinforce each other in East Asia (Table 8). The age structure effects are by far the largest in East Asia, and particularly in the Republic of Korea; Hong Kong, China; and Taipei,China. In those economies, age structure changes will raise government expenditure by 2.5-4.9 percentage points as a share of GDP by 2050 . The effects are large in other economies, but nowhere near this large. The interaction effects are by far the largest in East Asia.

Somewhat surprisingly, the increase is much smaller in other Asian countries which are also aging rapidly, for example Thailand. There are two underlying reasons for this. First, aging in poorer countries has a smaller impact because welfare expenditures often do not rise as rapidly with age as in richer countries. While their welfare spending is projected to reach higher levels between now and 2050, the increase in pensions, health care, and other elderly-oriented expenditures will be more limited than in richer countries. The second factor is the shape of the age profile. An increase in the $70+$ population has a much bigger impact on expenditure than an increase in the number of 60-yearolds. East Asian developing member economies are further along in their aging process and hence 
relative to Thailand, the very elderly account for a larger share of the increase in the old-age population.

The decomposition analysis for government revenue is presented in Table 9. We do not report the results for tax revenue and government revenue separately since the decomposition results are same. All changes in government revenue are driven by tax revenue, not by nontax revenue. Nontax revenues and grants are assumed to increase as a fixed share of GDP in our model.

The share of the working-age population is declining in East Asian economies and, hence, the impact of changing population age structure is to reduce tax revenues in this region. The impact is not big enough to offset the increase in tax revenues though. On average, changing age structure could reduce tax revenues by between $6 \%$ and $8 \%$ in East Asia. The same is true for Singapore and Thailand too. On the other hand, most countries in South Asia and Southeast Asia experience increases in tax revenues between 2010 and 2050 . The effects in others regions vary a lot, ranging from $1 \%$ to $21 \%$. The interaction effect is quite small.

The effects of changes in the level of taxation are nonnegative in every country since the per capita age-specific level of taxation is assumed to rise as countries grow richer. The rising level of agespecific tax is large enough to offset the effects of changing age structure in all countries. The agespecific tax revenue increase is largest in countries that are expected to grow rapidly, such as the PRC and Thailand. This is due to the assumptions underlying our projections, which are based on observed data.

Table 9 shows the decomposition of the fiscal balance. The last columns are negative if fiscal balance worsens and positive if it improves. If the contribution due to age-specific change in the level is nil for both revenue and expenditure, then all change is due to age structure. For example, most countries in Central and West Asia, and the Pacific will not experience any changes due to change in growth. All changes in their fiscal balance will thus be due to change in their age structure. Only demographic effects matter in countries that are very poor, or grow very slowly, and hence do not reach the income threshold that leads to an upward shift in the health profile. At the same time, only demographics matter in very rich economies such as Hong Kong, China; Singapore; or Japan, for the same underlying reason.

Although some Asian economies are currently in good fiscal shape compared with other regions of the world, such as Europe or Latin America (Roy 2015), there is no guarantee that their fiscal health will last. The Republic of Korea is an example of a country that is expected to simultaneously face a substantial fiscal deficit, slower economic growth, and population aging. Population aging will significantly harm the fiscal health of all East Asian economies. However, healthy economic growth could offset some of the negative impact of population aging. The PRC, which is assumed to grow rapidly until 2050 in our model, is a case in point. But in the Republic of Korea and Taipei,China, both the age effect and the age-specific level effects will adversely affect the fiscal balance. In contrast, both the age effect and the age-specific level effects are benign and mutually reinforcing in many South Asian countries. The size of working-age population is still growing in these countries, while social welfare spending remains limited. High growth rate is the key driver of the region's fiscal improvement. 
Table 8: Tax Revenue, Decomposition of Change (\% of GDP)

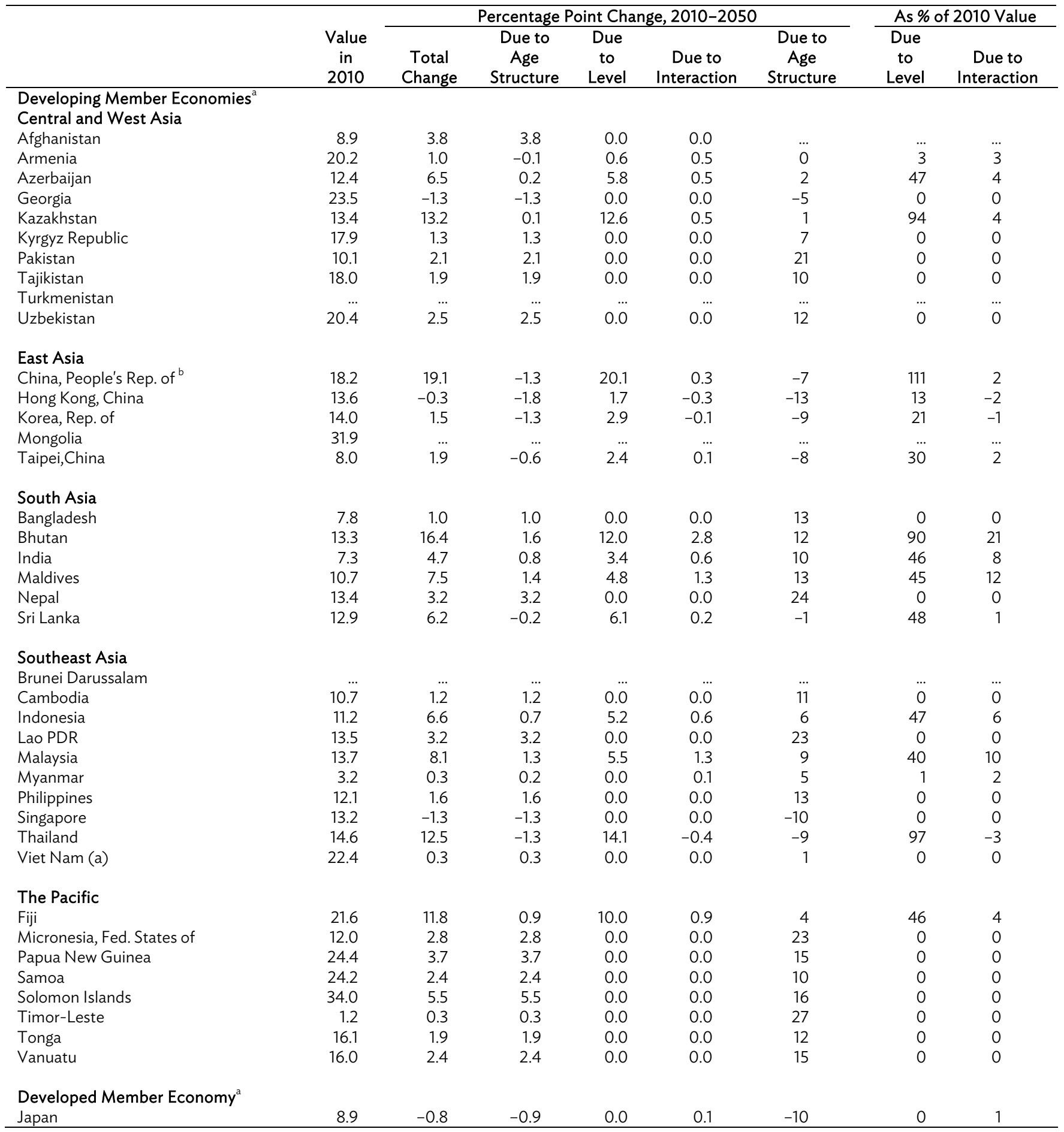

... = data not available, GDP = gross domestic product, Lao PDR = Lao People's Democratic Republic.

a Data refer to central government, except for Bangladesh, Georgia, Kiribati, the Kyrgyz Republic, Pakistan, and Tajikistan, where data refer to consolidated government or general government.

b Tax revenue includes local government tax revenue.

Source: ADB and authors' calculations. 
Table 9: Government Revenue, Decomposition of Change (\% of GDP)

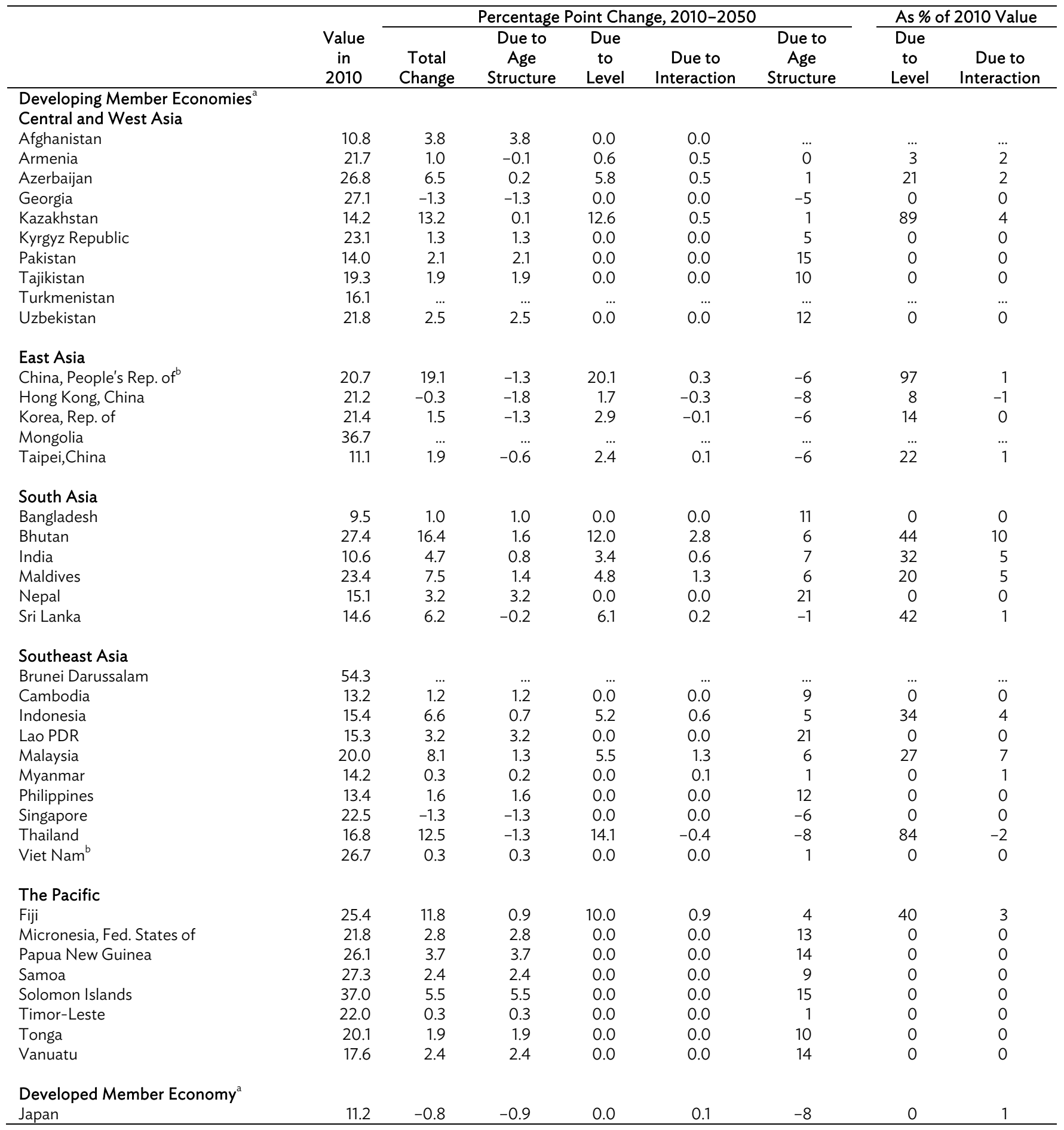

... = data not available, GDP = gross domestic product, Lao PDR = Lao People's Democratic Republic.

a. Data refer to central government, except for Bangladesh, Georgia, Kiribati, the Kyrgyz Republic, Pakistan, and Tajikistan, where data refer to consolidated government or general government.

b Government revenue includes local government revenue.

Source: ADB and authors' calculations. 
Table 10: Fiscal Balance, Decomposition of Change

(\% of GDP)

\begin{tabular}{|c|c|c|c|c|c|c|c|c|}
\hline & \multirow[b]{2}{*}{$\begin{array}{l}\text { Value } \\
\text { in } \\
2010\end{array}$} & \multicolumn{5}{|c|}{ Percentage Point Change, 2010-2050 } & \multicolumn{2}{|c|}{$\begin{array}{c}\text { As } \% \text { of Percentage } \\
\text { Point Change, } \\
2010-2050\end{array}$} \\
\hline & & $\begin{array}{c}\text { Total } \\
\text { Change }\end{array}$ & $\begin{array}{l}\text { Due to } \\
\text { Age } \\
\text { Structure }\end{array}$ & $\begin{array}{l}\text { Due } \\
\text { to } \\
\text { Level }\end{array}$ & $\begin{array}{c}\text { Due to } \\
\text { Interaction }\end{array}$ & $\begin{array}{l}\text { Due to } \\
\text { Age } \\
\text { Structure }\end{array}$ & $\begin{array}{l}\text { Due } \\
\text { to } \\
\text { Level }\end{array}$ & $\begin{array}{l}\text { Due to } \\
\text { Interaction }\end{array}$ \\
\hline \multicolumn{9}{|c|}{$\begin{array}{l}\text { Developing Member Economies }{ }^{\mathrm{a}} \\
\text { Central and West Asia }\end{array}$} \\
\hline Afghanistan & $\ldots$ & $\ldots$ & $\ldots$ & $\ldots$ & $\ldots$ & $\ldots$ & $\ldots$ & $\ldots$ \\
\hline Armenia & -5.0 & 2.9 & -1.5 & 4.0 & 0.4 & -51 & 138 & 14 \\
\hline Azerbaijan & -0.9 & -3.5 & -4.2 & 0.4 & 0.3 & -120 & 11 & 9 \\
\hline Georgia & -5.6 & -3.5 & -3.5 & 0.0 & 0.0 & -100 & 0 & 0 \\
\hline Kazakhstan & $\ldots$ & $\ldots$ & $\ldots$ & $\ldots$ & $\ldots$ & $\ldots$ & $\ldots$ & $\ldots$ \\
\hline Kyrgyz Republic & -4.9 & -0.9 & -0.9 & 0.0 & 0.0 & -100 & 0 & 0 \\
\hline Pakistan & $\ldots$ & $\ldots$ & $\ldots$ & $\ldots$ & $\ldots$ & $\ldots$ & $\ldots$ & $\ldots$ \\
\hline Tajikistan & -7.1 & 0.3 & 0.3 & 0.0 & 0.0 & 100 & 0 & 0 \\
\hline Turkmenistan & $\ldots$ & $\ldots$ & $\ldots$ & $\ldots$ & $\ldots$ & $\ldots$ & $\ldots$ & $\ldots$ \\
\hline Uzbekistan & $\ldots$ & $\ldots$ & $\ldots$ & $\ldots$ & $\ldots$ & $\ldots$ & $\ldots$ & $\ldots$ \\
\hline \multicolumn{9}{|l|}{ East Asia } \\
\hline China, People's Rep. of ${ }^{b}$ & -1.7 & 7.7 & -2.8 & 13.1 & -2.6 & -37 & 171 & -34 \\
\hline Hong Kong, China & 4.2 & -5.2 & -4.7 & 0.3 & -0.9 & -90 & 6 & -17 \\
\hline Korea, Rep. of & 1.3 & -11.0 & -5.8 & -0.8 & -4.4 & -52 & -8 & -40 \\
\hline Mongolia & 0.5 & $\ldots$ & $\ldots$ & $\ldots$ & ... & $\ldots$ & $\ldots$ & ... \\
\hline Taipei,China & -2.8 & -12.4 & -5.5 & -2.0 & -4.8 & -45 & -16 & -39 \\
\hline \multicolumn{9}{|l|}{ South Asia } \\
\hline Bangladesh & -2.8 & 1.2 & 1.2 & 0.0 & 0.0 & 100 & 0 & 0 \\
\hline Bhutan & 1.5 & 8.4 & 1.3 & 5.1 & 2.0 & 16 & 61 & 23 \\
\hline India & -4.8 & 2.2 & 0.3 & 1.3 & 0.6 & 14 & 57 & 29 \\
\hline Maldives & -15.6 & 3.6 & 3.6 & 0.0 & 0.0 & 100 & 0 & 0 \\
\hline Nepal & -3.5 & 3.4 & -1.1 & 4.5 & 0.0 & -33 & 132 & 1 \\
\hline Sri Lanka & -8.0 & 3.6 & 0.8 & 2.2 & 0.5 & 22 & 63 & 15 \\
\hline \multicolumn{9}{|l|}{ Southeast Asia } \\
\hline Brunei Darussalam & $\ldots$ & $\ldots$ & $\ldots$ & $\ldots$ & $\ldots$ & $\ldots$ & $\ldots$ & $\ldots$ \\
\hline Cambodia & -3.2 & 4.7 & 0.0 & 4.2 & 0.5 & -1 & 90 & 11 \\
\hline Indonesia & -0.7 & 2.6 & 2.6 & 0.0 & 0.0 & 100 & 0 & 0 \\
\hline Lao PDR & -2.2 & 4.9 & 1.9 & 1.9 & 1.1 & 39 & 38 & 23 \\
\hline Malaysia & $\ldots$ & $\ldots$ & $\ldots$ & $\ldots$ & $\ldots$ & $\ldots$ & $\ldots$ & $\ldots$ \\
\hline Myanmar & -4.6 & 0.9 & 0.9 & 0.0 & 0.0 & 100 & 0 & 0 \\
\hline Philippines & -3.5 & 1.6 & 1.6 & 0.0 & 0.0 & 100 & 0 & 0 \\
\hline Singapore & 7.7 & -1.3 & -1.3 & 0.0 & 0.0 & -100 & 0 & 0 \\
\hline Thailand & $\ldots$ & $\ldots$ & $\ldots$ & $\ldots$ & $\ldots$ & $\ldots$ & $\ldots$ & $\ldots$ \\
\hline Viet $\mathrm{Nam}^{\mathrm{b}}$ & -2.1 & 5.6 & -1.9 & 9.1 & -1.5 & -35 & 162 & -28 \\
\hline \multicolumn{9}{|l|}{ The Pacific } \\
\hline Fiji & $\ldots$ & $\ldots$ & $\ldots$ & $\ldots$ & $\ldots$ & $\ldots$ & $\ldots$ & $\ldots$ \\
\hline Micronesia, Fed. States of & 0.5 & 2.1 & 2.1 & 0.0 & 0.0 & 100 & 0 & 0 \\
\hline Papua New Guinea & $\ldots$ & $\ldots$ & $\ldots$ & $\ldots$ & $\ldots$ & $\ldots$ & $\ldots$ & $\ldots$ \\
\hline Samoa & -7.4 & 2.8 & 2.8 & 0.0 & 0.0 & 100 & 0 & 0 \\
\hline Solomon Islands & 8.3 & 9.6 & 1.1 & 7.9 & 0.6 & 12 & 82 & 6 \\
\hline Timor-Leste & 3.5 & 0.1 & 0.1 & 0.0 & 0.0 & 100 & 0 & 0 \\
\hline Tonga & -2.7 & 1.7 & 1.7 & 0.0 & 0.0 & 100 & 0 & 0 \\
\hline Vanuatu & -2.0 & 4.2 & 4.2 & 0.0 & 0.0 & 100 & 0 & 0 \\
\hline \multicolumn{9}{|c|}{ Developed Member Economy ${ }^{a}$} \\
\hline Japan & -6.7 & -7.6 & -7.1 & 0.0 & -0.6 & -93 & 0 & -7 \\
\hline
\end{tabular}

... = data not available, GDP = gross domestic product, Lao PDR = Lao People's Democratic Republic.

a Data refer to central government, except for Bangladesh, Georgia, Kiribati, the Kyrgyz Republic, Pakistan, and Tajikistan, where data refer to consolidated government or general government.

b Fiscal balance includes local government balance.

Source: ADB and authors' calculations. 


\section{CONCLUDING OBSERVATIONS}

While data limitations impede our analysis of the relationship between demographic change and fiscal sustainability in Asia, our findings nevertheless point to some important issues and considerations. The worsening fiscal health of economies like the Republic of Korea; Japan; and Taipei,China, suggests that current tax and expenditure systems cannot guarantee future fiscal sustainability in aging Asian economies. On a more optimistic note, low-income economies, which are still enjoying an expansion of the working-age population under the second phase of the demographic transition, can help their own fiscal position substantially by growing rapidly. At the same time, it should be noted that population aging is a universal feature of Asian economies. Only the timing and speed of the demographic transition varies and sooner or later they will face a deterioration of their fiscal health in the future, following the footsteps of the Republic of Korea; Japan; and Taipei,China.

Our results for individual countries is based less on what we know about individual countries and more on what we see as broad patterns across the region based on selective data available for countries at different levels of development. Data about the interaction between the population age structure and the economy are underdeveloped. The age profiles of tax burdens and benefits are available for only a few countries. Little is known about how slow growth and population aging will influence the fiscal sustainability in the coming decades. This points to an urgent need to improve the quality of data, particularly data on public transfers in Asian countries.

Public programs are providing important sources of support for the elderly, especially in richer Asian countries. The key question is how to sustain or reform current old-age support systems in the face of rapid population aging. Our results show that population aging leads to very substantial increases in public spending and decrease in revenue even with constant age profiles. A critical priority everywhere is to improve our understanding of the connection between age, tax burden, and needs for support. Unfortunately, current policies often depend on definitions of working age or old age that are arbitrary and perhaps increasingly out of touch. 


\section{APPENDIX}

Table A.1: Government Tax Revenue (holding 2010 fiscal balance constant) (\% of GDP)

\begin{tabular}{|c|c|c|c|c|c|c|c|c|}
\hline & 1995 & 2000 & 2005 & 2010 & 2020 & 2030 & 2040 & 2050 \\
\hline \multicolumn{9}{|c|}{$\begin{array}{l}\text { Developing Member Economies } \\
\text { Central and West Asia }\end{array}$} \\
\hline Afghanistan & $\ldots$ & $\ldots$ & 3.8 & 8.9 & $\ldots$ & $\ldots$ & $\ldots$ & 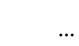 \\
\hline Armenia & 10.6 & 14.8 & 14.3 & 20.2 & 20.5 & 17.0 & 17.0 & 18.3 \\
\hline Azerbaijan & 10.8 & 12.2 & 14.0 & 12.4 & 13.0 & 20.5 & 21.4 & 22.4 \\
\hline Georgia & $\ldots$ & 14.6 & 20.8 & 23.5 & 24.2 & 25.3 & 25.3 & 25.7 \\
\hline Kazakhstan & 15.8 & 20.2 & 26.3 & 13.4 & $\ldots$ & $\ldots$ & $\ldots$ & \\
\hline Kyrgyz Republic & 15.1 & 11.7 & 16.2 & 17.9 & 18.0 & 19.4 & 19.5 & 20.1 \\
\hline Pakistan & 13.8 & 10.6 & 10.1 & 10.1 & $\ldots$ & $\ldots$ & $\ldots$ & \\
\hline Tajikistan & 8.4 & 13.1 & 16.5 & 18.0 & 18.1 & 19.0 & 19.1 & 19.5 \\
\hline Turkmenistan & $\ldots$ & 23.0 & $\ldots$ & $\ldots$ & $\ldots$ & $\ldots$ & $\ldots$ & $\ldots$ \\
\hline Uzbekistan & 27.8 & $\ldots$ & 21.5 & 20.4 & $\ldots$ & $\ldots$ & $\ldots$ & $\ldots$ \\
\hline \multicolumn{9}{|l|}{ East Asia } \\
\hline China, People's Rep. of ${ }^{b}$ & 9.9 & 12.7 & 15.6 & 18.2 & 21.0 & 21.9 & 25.1 & 29.7 \\
\hline Hong Kong, China & 11.2 & 9.7 & 12.3 & 13.6 & 15.3 & 17.3 & 18.0 & 18.5 \\
\hline Korea, Rep. of & 15.2 & 17.0 & 13.9 & 14.0 & 15.1 & 22.4 & 25.1 & 26.6 \\
\hline Mongolia & 16.2 & 21.3 & 22.8 & 31.9 & $\ldots$ & $\ldots$ & $\ldots$ & \\
\hline Taipei,China & 10.3 & 13.3 & 9.1 & 8.0 & 10.7 & 15.1 & 20.0 & 22.3 \\
\hline \multicolumn{9}{|l|}{ South Asia } \\
\hline Bangladesh & 7.9 & 6.8 & 8.6 & 7.8 & 7.6 & 7.6 & 7.6 & 7.7 \\
\hline Bhutan & 6.6 & 10.0 & 9.4 & 13.3 & 12.6 & 16.2 & 16.7 & 21.3 \\
\hline India & 6.9 & 6.5 & 7.3 & 7.3 & 6.1 & 4.3 & 4.4 & 9.8 \\
\hline Maldives & 13.6 & 13.8 & 13.6 & 10.7 & 10.1 & 15.0 & 14.9 & 14.6 \\
\hline Nepal & 8.4 & 8.1 & 9.2 & 13.4 & 15.1 & 12.1 & 12.8 & 13.1 \\
\hline Sri Lanka & 17.9 & 14.2 & 13.7 & 12.9 & 12.4 & 18.3 & 18.3 & 15.5 \\
\hline \multicolumn{9}{|l|}{ Southeast Asia } \\
\hline Brunei Darussalam & 18.4 & 23.4 & 33.1 & $\ldots$ & $\ldots$ & $\ldots$ & $\ldots$ & \\
\hline Cambodia & 5.3 & 7.3 & 7.7 & 10.7 & 11.0 & 11.3 & 11.7 & 7.2 \\
\hline Indonesia & 16.0 & 8.3 & 12.5 & 11.2 & 10.5 & 9.9 & 9.4 & 15.2 \\
\hline Lao PDR & 9.4 & 10.6 & 9.7 & 13.5 & 12.8 & 10.3 & 10.9 & 11.7 \\
\hline Malaysia & 18.7 & 13.2 & 14.8 & 13.7 & $\ldots$ & $\ldots$ & $\ldots$ & $\ldots$ \\
\hline Myanmar & 3.7 & 2.0 & $\ldots$ & 3.2 & 2.7 & 2.6 & 2.3 & 2.6 \\
\hline Philippines & 16.3 & 12.8 & 12.4 & 12.1 & 12.1 & 12.1 & 12.1 & 12.2 \\
\hline Singapore & 15.9 & 15.1 & 11.5 & 13.2 & 13.0 & 13.2 & 13.3 & 13.3 \\
\hline Thailand & 16.4 & 12.8 & 15.3 & 14.6 & $\ldots$ & $\ldots$ & $\ldots$ & $\ldots$ \\
\hline Viet Nam ${ }^{b}$ & 19.1 & 18.0 & 21.0 & 22.4 & 23.3 & 19.7 & 20.6 & 17.1 \\
\hline \multicolumn{9}{|l|}{ The Pacific } \\
\hline Fiji & 21.9 & 19.9 & 21.0 & 21.6 & $\ldots$ & $\ldots$ & $\ldots$ & \\
\hline Micronesia, Fed. States of & 9.5 & 11.9 & 11.7 & 12.0 & 13.0 & 13.0 & 13.0 & 12.7 \\
\hline Papua New Guinea & 19.5 & 23.8 & 24.8 & 24.4 & $\ldots$ & $\ldots$ & $\ldots$ & $\ldots$ \\
\hline Samoa & 22.5 & 20.6 & 20.6 & 24.2 & 23.6 & 23.3 & 23.4 & 23.9 \\
\hline Solomon Islands & 21.4 & 19.1 & 24.3 & 34.0 & 35.1 & 36.5 & 37.4 & 30.0 \\
\hline Timor-Leste & $\ldots$ & $\ldots$ & 1.5 & 1.2 & 1.1 & 0.9 & 0.9 & 1.5 \\
\hline Tonga & 13.4 & 15.8 & 19.2 & 16.1 & 16.3 & 16.1 & 16.2 & 16.4 \\
\hline Vanuatu & 19.6 & 15.7 & 16.4 & 16.0 & 15.7 & 15.2 & 14.8 & 14.3 \\
\hline \multicolumn{9}{|c|}{ Developed Member Economy ${ }^{a}$} \\
\hline Japan & 10.7 & 10.4 & 10.2 & 8.9 & 11.4 & 12.8 & 14.8 & 15.7 \\
\hline
\end{tabular}

... = data not available, GDP = gross domestic product, Lao PDR = Lao People's Democratic Republic.

a Data refer to central government, except for Bangladesh, Georgia, Kiribati, the Kyrgyz Republic, Pakistan, and Tajikistan, where data refer to consolidated government or general government.

b Tax revenue includes local government tax revenue.

Source: ADB and authors' calculations. 


\section{Table A.2: Government Revenue (holding 2010 fiscal balance constant)} (\% of GDP)

\begin{tabular}{|c|c|c|c|c|c|c|c|c|}
\hline & 1995 & 2000 & 2005 & 2010 & 2020 & 2030 & 2040 & 2050 \\
\hline \multicolumn{9}{|c|}{ Developing Member Economies ${ }^{a}$} \\
\hline \multicolumn{9}{|c|}{ Central and West Asia } \\
\hline Afghanistan & $\ldots$ & $\ldots$ & 6.9 & 10.8 & $\ldots$ & $\ldots$ & $\ldots$ & $\ldots$ \\
\hline Armenia & 14.4 & 15.9 & 16.2 & 21.7 & 22.0 & 18.5 & 18.5 & 19.8 \\
\hline Azerbaijan & 11.8 & 14.7 & 16.3 & 26.8 & 27.5 & 34.9 & 35.8 & 36.8 \\
\hline Georgia & $\ldots$ & 15.5 & 27.1 & 27.1 & 27.8 & 28.9 & 28.9 & 29.2 \\
\hline Kazakhstan & 19.6 & 22.9 & 27.6 & 14.2 & $\ldots$ & $\ldots$ & $\ldots$ & $\ldots$ \\
\hline Kyrgyz Republic & 16.7 & 14.2 & 19.8 & 23.1 & 23.2 & 24.7 & 24.7 & 25.3 \\
\hline Pakistan & 17.3 & 13.4 & 13.8 & 14.0 & $\ldots$ & $\ldots$ & $\ldots$ & $\ldots$ \\
\hline Tajikistan & 10.0 & 14.1 & 19.2 & 19.3 & 19.4 & 20.3 & 20.4 & 20.9 \\
\hline Turkmenistan & 20.5 & 23.5 & 20.5 & 16.1 & $\ldots$ & $\ldots$ & $\ldots$ & $\ldots$ \\
\hline Uzbekistan & 29.7 & 28.0 & 22.6 & 21.8 & $\ldots$ & $\ldots$ & $\ldots$ & $\ldots$ \\
\hline \multicolumn{9}{|l|}{ East Asia } \\
\hline China, People's Rep. of ${ }^{b}$ & 10.3 & 13.5 & 17.1 & 20.7 & 23.5 & 24.4 & 27.6 & 32.2 \\
\hline Hong Kong, China & 16.1 & 16.8 & 17.5 & 21.2 & 22.9 & 24.9 & 25.6 & 26.1 \\
\hline Korea, Rep. of & 17.8 & 21.4 & 20.8 & 21.4 & 22.5 & 29.8 & 32.5 & 33.9 \\
\hline Mongolia & 20.8 & 28.3 & 27.4 & 36.7 & $\ldots$ & $\ldots$ & $\ldots$ & $\ldots$ \\
\hline Taipei,China & 13.3 & 18.0 & 14.8 & 11.1 & 13.9 & 18.2 & 23.2 & 25.4 \\
\hline \multicolumn{9}{|l|}{ South Asia } \\
\hline Bangladesh & 9.8 & 8.5 & 10.6 & 9.5 & 9.3 & 9.3 & 9.3 & 9.4 \\
\hline Bhutan & 19.1 & 23.2 & 17.0 & 27.4 & 26.7 & 30.3 & 30.8 & 35.4 \\
\hline India & 9.9 & 9.8 & 9.7 & 10.6 & 9.3 & 7.5 & 7.7 & 13.0 \\
\hline Maldives & 25.8 & 30.0 & 29.8 & 23.4 & 22.8 & 27.7 & 27.6 & 27.2 \\
\hline Nepal & 10.4 & 10.5 & 11.9 & 15.1 & 16.8 & 13.8 & 14.5 & 14.8 \\
\hline Sri Lanka & 20.6 & 16.4 & 15.5 & 14.6 & 14.1 & 20.0 & 19.9 & 17.2 \\
\hline \multicolumn{9}{|l|}{ Southeast Asia } \\
\hline Brunei Darussalam & 36.5 & 49.1 & 53.2 & 54.3 & $\ldots$ & $\ldots$ & $\ldots$ & $\ldots$ \\
\hline Cambodia & 7.6 & 10.0 & 10.6 & 13.2 & 13.6 & 13.9 & 14.3 & 9.7 \\
\hline Indonesia & 17.7 & 14.7 & 17.8 & 15.4 & 14.7 & 14.1 & 13.5 & 19.4 \\
\hline Lao PDR & 11.1 & 13.1 & 11.7 & 15.3 & 14.7 & 12.2 & 12.8 & 13.5 \\
\hline Malaysia & 22.9 & 17.4 & 19.6 & 20.0 & $\ldots$ & $\ldots$ & $\ldots$ & $\ldots$ \\
\hline Myanmar & 6.5 & 4.2 & $\ldots$ & 14.2 & 13.7 & 13.6 & 13.3 & 13.6 \\
\hline Philippines & 18.9 & 14.3 & 14.4 & 13.4 & 13.4 & 13.4 & 13.4 & 13.4 \\
\hline Singapore & 34.8 & 29.8 & 20.7 & 22.5 & 22.3 & 22.4 & 22.6 & 22.6 \\
\hline Thailand & 18.1 & 14.7 & 17.4 & 16.8 & $\ldots$ & $\ldots$ & $\ldots$ & $\ldots$ \\
\hline Viet $\mathrm{Nam}^{\mathrm{b}}$ & 21.9 & 20.1 & 25.7 & 26.7 & 27.7 & 24.0 & 24.9 & 21.4 \\
\hline \multicolumn{9}{|l|}{ The Pacific } \\
\hline Fiji & 25.5 & 25.4 & 23.9 & 25.4 & $\ldots$ & $\ldots$ & $\ldots$ & $\ldots$ \\
\hline Micronesia, Fed. States of & 26.4 & 22.5 & 20.8 & 21.8 & 22.8 & 22.9 & 22.8 & 22.5 \\
\hline Papua New Guinea & 24.0 & 25.7 & 26.8 & 26.1 & $\ldots$ & $\ldots$ & $\ldots$ & $\ldots$ \\
\hline Samoa & 29.9 & 25.6 & 24.0 & 27.3 & 26.7 & 26.3 & 26.4 & 26.9 \\
\hline Solomon Islands & 27.7 & 21.6 & 26.7 & 37.0 & 38.1 & 39.5 & 40.4 & 33.0 \\
\hline Timor-Leste & $\ldots$ & $\ldots$ & 9.7 & 22.0 & 21.9 & 21.7 & 21.7 & 22.2 \\
\hline Tonga & 25.6 & 21.1 & 22.8 & 20.1 & 20.4 & 20.2 & 20.2 & 20.4 \\
\hline Vanuatu & 24.2 & 18.7 & 18.5 & 17.6 & 17.3 & 16.8 & 16.4 & 15.9 \\
\hline \multicolumn{9}{|c|}{ Developed Member Economy ${ }^{a}$} \\
\hline Japan & 12.2 & 12.0 & 11.9 & 11.2 & 13.8 & 15.1 & 17.1 & 18.1 \\
\hline
\end{tabular}




\section{REFERENCES*}

Alesina, A., and R. Wacziarg. 1998. Openness, Country Size, and Government. Journal of Public Economics. 69. pp. 305-21.

Estrada, G., S.-H. Lee, and D. Park. 2015. An overview. In D. Park, S.-H. Lee, and M. Lee, eds. Fiscal Policy, Inequality, and Inclusive Growth in Asia. Oxon, UK, and New York, NY, US: Routledge.

Hines, J. R., and L. H. Summers. 2009. How Globalization Affects Tax Design. NBER Working Paper 14664. National Bureau of Economic Research.

Kim, S. T. 2015. Lessons from Japan's Fiscal Policy for Korea. Presented at the EWC/KDI Conference on Japanization: Causes and Remedies. Hawaii, US. 10-11 August.

Lee, R. D. 1994a. The Formal Demography of Population Aging, Transfers, and the Economic Life Cycle. In L. G. Martin and S. H. Preston. Demography of Aging. Washington, DC: National Academy Press.

- 1994b. Population, Age Structure, Intergenerational Transfers, and Wealth: A New Approach with Applications to the United States. P. Gertler. The Family and Intergenerational Relations. The Journal of Human Resources. 29 (4). pp. 1027-63.

Lee, R. D., S.-H. Lee, and A. Mason. 2008. Charting the Economic Lifecycle. A. Prskawetz, D. E. Bloom, and W. Lutz. Population Aging, Human Capital Accumulation, and Productivity Growth. Population and Development Review. 34. pp. 208-37.

Lee, R., and A. Mason. 2011. Population Aging and the Generational Economy: A Global Perspective. Cheltenham, UK: Edward Elgar.

Lee, S.-H., and A. Mason. 2015. Are Current Tax and Spending Regimes Sustainable in Developing Asia? D. Park, S-H Lee, and M. Lee, eds. Fiscal Policy, Inequality, and Inclusive Growth in Asia. Oxon, UK and New York, NY, US: Routledge.

Li, W., and P. D. Sarte. 2004. Progressive Taxation and Long-Run Growth. American Economic Review. 94 (5). pp. 1705-16.

Martinez-Vazquez, J., V. Vulovic, Y. Liu. 2009. Direct versus Indirect Taxation: Trends, Theory and Economic Significance. International Studies Program WP 09-11.

Mason, A., R. Lee, A.-C. Tung, M.-S. Lai, and T. Miller. 2009. Population Aging and Intergenerational Transfers: Introducing Age into National Accounts. In D. Wise, ed. Developments in the Economics of Aging. Chicago: NBER and University of Chicago Press.

National Assembly Budget Office. 2015. White Paper. Republic of Korea.

National Transfer Accounts. www.ntaccounts.org

* ADB recognizes "Korea" as the Republic of Korea. 
Persson, T., and G. Tabellini. 2004. Constitutions and Economic Policy. Journal of Economic Perspectives. 18 (1). pp. 75-98.

Rodrik, D. 1996. Why Do More Open Economies Have Bigger Governments? The Journal of Political Economy. 106 (5). pp. 997-1032.

Roy, R. 2015. Room at the Top: An Overview of Fiscal Space, Fiscal Policy, and Inclusive Growth in Developing Asia. In D. Park, S.-H. Lee, and M. Lee, eds. Fiscal Policy, Inequality, and Inclusive Growth in Asia. Oxon, UK and New York, NY, US: Routledge.

United Nations Population Division. 2013a. World Population Prospects: The 2012 Revision. New York: United Nations.

2. 2013b. National Transfer Accounts Manual: Measuring and Analyzing the Generational Economy. New York: United Nations. 


\section{Demographic Change and Fiscal Sustainability in Asia}

Population structure affects government revenues as well as expenditures. For example, a younger population requires more public spending on education. The authors use a simple stylized model and National Transfer Accounts data set to simulate the effect of Asia's population aging and economic growth on the region's fiscal sustainability. While there are differences across countries, with some countries more affected than others, overall, the simulation results clearly indicate that demographic change will adversely affect Asia's fiscal health. This points to a need for Asian countries to better understand and prepare for the fiscal impact of population aging.

\section{About the Asian Development Bank}

ADB's vision is an Asia and Pacific region free of poverty. Its mission is to help its developing member countries reduce poverty and improve the quality of life of their people. Despite the region's many successes, it remains home to the majority of the world's poor. $A D B$ is committed to reducing poverty through inclusive economic growth, environmentally sustainable growth, and regional integration.

Based in Manila, ADB is owned by 67 members, including 48 from the region. Its main instruments for helping its developing member countries are policy dialogue, loans, equity investments, guarantees, grants, and technical assistance. 